\title{
THE
}

\section{A Case Study of Ships Forming and Not Forming Tracks in Moderately Polluted Clouds}

\author{
Kevin J. Noone \\ Elisabeth Öström \\ Ronald J. Ferek \\ Tim Garrett \\ Peter V. Hobbs
}

See next page for additional authors

Follow this and additional works at: https://digitalcommons.uri.edu/gsofacpubs

Terms of Use

All rights reserved under copyright.

\section{Citation/Publisher Attribution}

Noone, K.J., E. Öström, R.J. Ferek, T. Garrett, P.V. Hobbs, D.W. Johnson, J.P. Taylor, L.M. Russell, R.C. Flagan, J.H. Seinfeld, C.D. O’Dowd, M.H. Smith, P.A. Durkee, K. Nielsen, J.G. Hudson, R.A. Pockalny, L. De Bock, R.E. Van Grieken, R.F. Gasparovic, and I. Brooks, 2000: A Case Study of Ships Forming and Not Forming Tracks in Moderately Polluted Clouds. J. Atmos. Sci., 57, 2729-274. doi: 10.1175/ 1520-0469(2000)0572.0.CO;2 Available at: https://doi.org/10.1175/1520-0469(2000)0572.0.C0;2

This Article is brought to you for free and open access by the Graduate School of Oceanography at DigitalCommons@URI. It has been accepted for inclusion in Graduate School of Oceanography Faculty Publications by an authorized administrator of DigitalCommons@URI. For more information, please contact digitalcommons-group@uri.edu. 


\section{Authors}

Kevin J. Noone, Elisabeth Öström, Ronald J. Ferek, Tim Garrett, Peter V. Hobbs, Doug W. Johnson, Lynn M. Russell, Richard C. Flagan, John H. Seinfeld, Colin D. O'Dowd, Michael H. Smith, Philip A. Durkee, Kurt Nielsen, James G. Hudson, Robert Pockalny, Lieve De Bock, René E. Van Grieken, Richard F. Gasparovic, and Ian Brooks 


\title{
A Case Study of Ships Forming and Not Forming Tracks in Moderately Polluted Clouds
}

\author{
Kevin J. NoOne, ${ }^{a}$ Elisabeth Öström, ${ }^{a}$ Ronald J. Ferek, ${ }^{b, m}$ Tim Garrett, ${ }^{b}$ Peter V. Hobbs, ${ }^{b}$ \\ Doug W. Johnson, ${ }^{c}$ Jonathan P. Taylor, ${ }^{c}$ Lynn M. Russell, ${ }^{d}$ Richard C. Flagan, ${ }^{e}$ John H. Seinfeld, ${ }^{e}$ \\ Colin D. O’Dowd, ${ }^{\mathrm{f}}$ Michael H. Smith, ${ }^{\mathrm{f}}$ Philip A. Durkee,,${ }^{\mathrm{g}}$ Kurt Nielsen,,${ }^{\mathrm{g}}$ James G. Hudson, ${ }^{\mathrm{h}}$ \\ Robert A. Pockalny, ${ }^{i}$ Lieve De Bock,${ }^{j}$ René E. Van Grieken, ${ }^{j}$ \\ RICHARD F. GASPAROVIC, ${ }^{\mathrm{k}}$ AND IAN BROOKS ${ }^{1}$ \\ a Department of Meteorology, Stockholm University, Stockholm, Sweden \\ ${ }^{\mathrm{b}}$ Department of Atmospheric Sciences, University of Washington, Seattle, Washington \\ ' Meteorological Research Flight, The Met. Office, Farnborough, Hampshire, United Kingdom \\ ${ }^{d}$ Department of Chemical Engineering, Princeton University, Princeton, New Jersey \\ e Department of Chemical Engineering, California Institute of Technology, Pasadena, California \\ ${ }^{\mathrm{f}}$ Centre for Marine and Atmospheric Sciences, University of Sunderland, Sunderland, United Kingdom \\ g Department of Meteorology, Naval Postgraduate School, Monterey, California \\ ${ }^{\mathrm{h}}$ Desert Research Institute, University of Nevada, Reno, Nevada \\ Graduate School of Oceanography, University of Rhode Island, Narragansett, Rhode Island \\ ${ }^{j}$ Department of Chemistry, University of Antwerp, Wilrijk-Antwerp, Belgium \\ ${ }^{k}$ Applied Physics Laboratory, The Johns Hopkins University, Laurel, Maryland \\ ${ }^{1}$ Scripps Institution of Oceanography, University of California, San Diego, La Jolla, California
}

(Manuscript received 11 July 1996, in final form 25 February 1998)

\begin{abstract}
The effects of anthropogenic particulate emissions from ships on the radiative, microphysical, and chemical properties of moderately polluted marine stratiform clouds are examined. A case study of two ships in the same air mass is presented where one of the vessels caused a discernible ship track while the other did not. In situ measurements of cloud droplet size distributions, liquid water content, and cloud radiative properties, as well as aerosol size distributions (outside cloud, interstitial, and cloud droplet residual particles) and aerosol chemistry, are presented. These are related to measurements of cloud radiative properties. The differences between the aerosol in the two ship plumes are discussed; these indicate that combustion-derived particles in the size range of about $0.03-0.3-\mu \mathrm{m}$ radius were those that caused the microphysical changes in the clouds that were responsible for the ship track.

The authors examine the processes behind ship track formation in a moderately polluted marine boundary layer as an example of the effects that anthropogenic particulate pollution can have in the albedo of marine stratiform clouds.
\end{abstract}

\section{Introduction}

Clouds are one of the regulating factors controlling the radiative balance of the earth. Marine stratiform clouds in particular play a significant role in the radiation balance due to their large horizontal extent, their long lifetimes, and high reflectivity over an otherwise low-reflectivity surface. The reflectivity of warm, nonprecipitating marine stratiform clouds (their albedo) is

${ }^{m}$ Current affiliation: Office of Naval Research, Washington, D.C.

Corresponding author address: Dr. Kevin J. Noone, Department of Meteorology, Stockholm University, S-106 91 Stockholm, Sweden. E-mail: zippy@misu.su.se a function of their optical depth. If the cloud has a rather narrow droplet size distribution with a mean radius much greater than the wavelength range of visible light, the optical depth of the cloud is a function of the cloud liquid water content, the density of the cloud droplets, the vertical thickness of the cloud, and the cloud drop concentration (Twomey 1977).

Droplet number concentration and liquid water content can vary independently of each other. Making a given number of droplets larger by condensation of water vapor will increase the liquid water content without changing droplet number. Such condensation requires only that droplets be present in a supersaturated environment. To increase droplet number, on the other hand, requires that additional particles be present upon which new cloud droplets can form or a supersaturation increase in the cloud. 


\section{a. Anthropogenic effects on cloud albedo}

The link between pollution and planetary albedo was pointed out by Twomey (1974). The notion that anthropogenically produced particles can have an influence on cloud albedo has received a good deal of attention in recent years. Twomey (1991) derived an expression for the sensitivity of cloud reflectivity to changes in droplet number. He found that the most sensitive clouds were those with low droplet number concentrations and a reflectivity of 0.5 -conditions typical of marine stratiform clouds.

The fact that the clouds for which the change in reflectivity for a unit change in droplet number is largest are clouds with low droplet number concentrations has made anthropogenic influences on cloud albedo very difficult to detect. An analysis by Schwartz (1988) could not detect a difference in mean albedo for Northern and Southern Hemisphere clouds and thus could not detect any anthropogenic influence on cloud albedo. A subsequent investigation (Kim and Cess 1993) of low-level clouds off the east coasts of North America and Asia showed enhanced cloud albedos in the coastal boundaries where anthropogenic sulfate loadings are largest.

\section{b. Ship tracks and susceptibility}

Ship tracks have been observed in satellite images ever since the early TIROS satellites became operational three decades ago (Conover 1966). Even in the earliest images, the "anomalous cloud lines" were suspected to have been caused by additional aerosol particles produced by ships (Conover 1966; Twomey et al. 1968). More recent observations have strengthened the link between ships and "anomalous cloud lines" (Coakley et al. 1987; Ferek et al. 1998; Hindman et al. 1994; King et al. 1993; Radke et al. 1989).

While the early observations of ship tracks in the TIROS images were limited to the visible region of the spectrum, later observations have been expanded to several wavelengths. The advanced very high resolution radiometer (AVHRR) instrument on board the National Oceanic and Atmospheric Administration (NOAA) polar orbiting satellites employs five different wavelengths. While some ship tracks are apparent in the visible wavelengths, many more become noticeable at 3.7 $\mu \mathrm{m}$ (channel 3 of the AVHRR). Platnick and Twomey (1994) used AVHRR data to show that the sensitivity of cloud albedo to an increase in drop concentrationthe cloud susceptibility —of ship tracks was lower than the surrounding ambient clouds.

Ship tracks and anthropogenic perturbations of cloud albedo are manifestations of the same underlying phenomenon. We can use ship tracks to learn about the processes behind changes in cloud albedo due to human activities. To this end, the Monterey Area Ship Track (MAST) experiment was designed. A specific aim of the project was to determine exactly what ship-induced effect caused the ship track observable in satellite images. The general aim was to investigate the processes behind anthropogenic modification of cloud albedo.

\section{c. Questions to be addressed}

The MAST experiment was designed to test a set of 10 hypotheses regarding the causes of ship track formation and how the tracks are maintained for long periods in a convective boundary layer (Durkee et al. $2000 \mathrm{~b}$ ). Tests of the various hypotheses are reported in other papers (e.g., Durkee et al. 2000c; Ferek et al. 2000; Durkee et al. 2000a). In this paper we will focus on a case study of two isolated pollution sources - two ships encountered on 27 June 1994 in semipolluted conditions, one of which caused a measurable change in cloud properties, while the other did not.

In order to understand the effects of the ship effluents on the clouds we sampled, we must also examine the properties of the unperturbed clouds outside the area influenced by ship emissions. It is the differences between the background clouds and the ship tracks that will provide information about the processes behind cloud albedo modification due to anthropogenic pollution. We will begin by looking at the nature of the background boundary layer in terms of its thermodynamic properties, as well as the chemical and microphysical properties of the aerosol and cloud droplets in areas unaffected by ship emissions. We shall then compare and contrast the effects that two different ships in the same air mass had on clouds in the marine boundary layer with the aim of learning about the processes behind anthropogenic modification of cloud albedo.

The questions we will address here include the following.

- What are the thermodynamic characteristics of the marine boundary layer in which the ship tracks formed?

- What is the chemical and microphysical nature of the aerosol in the background boundary layer?

- What is the chemical and microphysical nature of the aerosol particles that grew to form cloud droplets and of the interstitial aerosol in the background clouds?

- What differences were observed between the ship tracks and the background clouds in which they formed?

- What were the differences in ship emissions that could help explain why one ship caused a ship track while the other did not?

- How can the results from this specific case study be used to improve our understanding of the more general issue of anthropogenic influence on cloud albedo?

\section{Experimental description}

The MAST experiment took place in June 1994 off the coast of central California. The experimental ap- 
proach involved coordinated missions of several platforms aimed at testing a specific subset of the 10 hypotheses mentioned above. The particular mission was defined each day depending on weather conditions, platform availability, and whether dedicated ships or ships of opportunity were available.

A number of different platforms were involved in the MAST experiment: three aircraft [the University of Washington (UW) Convair C-131A, Meteorological Research Flight (MRF) C-130 W Hercules, and the National Aeronautics and Space Administration ER-2], an airship (Naval Research Laboratory blimp), a research vessel (the R/V Glorita), and NOAA and Defense Meteorological Satellite Program satellites. In addition, various U.S. Navy vessels were available during certain periods of the experiment for special maneuvers. Ships of opportunity were investigated when navy vessels were not available. A detailed description of the platforms is given elsewhere (Durkee et al. 2000b).

\section{a. UW Convair C-131A}

The primary aim of investigators on the C-131A was to investigate the chemical and microphysical nature of aerosols and clouds and aerosol-cloud interactions. The instrumentation on the $\mathrm{C}-131 \mathrm{~A}$ has been described in detail by Hobbs et al. (1991). We will present data primarily from four of the C-131 instruments: total particle concentrations from a TSI Incorporated model 3760 condensation particle counter, which counts particles larger than $10-\mathrm{nm}$ radius; accumulation-mode particle concentrations from a wing-mounted Particle Measuring Systems (PMS) passive cavity aerosol spectrometer probe (PCASP-100X); droplet number concentration from a PMS forward scattering spectrometer probe (FSSP-100X); and liquid water content from a Gerber Scientific Inc. Particulate Volume Monitor (PVM$100 \mathrm{~A})$. In addition to the C-131's normal payload, several guest investigators made measurements aboard the aircraft during MAST. Cloud condensation nuclei (CCN) measurements were made using a continuousflow CCN spectrometer (Hudson 1989). Aerosol size distributions between 0.003 - and $0.1-\mu \mathrm{m}$ radius were measured using a radial differential mobility analyzer [RCAD (Zhang et al. 1995)]. A modified version of the MICRON algorithm (Wolfenbarger and Seinfeld 1990; Russell et al. 1995) was used to invert the size distribution measurements from the RCAD. The chemical and microphysical properties of droplet residual aerosol particles were measured using a counterflow virtual impactor (CVI) to sample the cloud drops (Noone et al. 1988, Ogren et al. 1985).

\section{b. MRF C-130 W Hercules (C-130)}

The Meteorological Research Flight (MRF), a part of the U.K. Meteorological Office, operates a Royal Air Force C-130 Hercules aircraft that has been modified to make it suited to a wide range of atmospheric research. A complete description of the standard meteorological instrumentation is given in Rogers et al. (1995), of the cloud physics instrumentation in Brown (1993) and Martin et al. (1994), and the radiation instrumentation in Kilsby et al. (1992) and Saunders et al. (1992). The thermal volatility and size distributions of aerosol particles were also measured aboard the C-130 (O’Dowd and Smith 1993).

The aim of the $\mathrm{C}-130$ investigators was to investigate the thermodynamic nature of the marine boundary layer, the microphysical and radiative properties of clouds, and the microphysics and chemistry of aerosol particles.

\section{c. $R / V$ Glorita}

The research vessel Glorita provided soundings of thermodynamic parameters during the experiment. In addition, instruments aboard included a condensation nuclei $(\mathrm{CN})$ counter, a cloud radar system, a side-scanning lidar, and a ceilometer.

\section{d. Ships investigated}

We examined emissions from two different ships in the same air mass: the USS Mount Vernon and the COS$\mathrm{CO} \mathrm{Tai} \mathrm{He}$. Some information about the two ships is given here; a more detailed description of the ships is presented in Hobbs et al. (2000).

The USS Mount Vernon (LSD 39) is a landing ship with a displacement of between 8600 and 13700 tons. The Mount Vernon burns navy distillate fuel to power two 600-psi boilers in which superheated steam is generated. This steam in turn drives two geared steam turbines, each driving a separate shaft. The total power of the propulsion system is approximately $18000 \mathrm{~kW}$. The Mount Vernon was engaged in special maneuvers during the measurement period of 27 June. The ship had entered the operations area from the southeast, and at 0800 local time (LT) began repeated legs alternately with and against the wind. The objective of this exercise was to examine whether the wind speed relative to the ship affected ship track formation. The ship steamed into the wind between 0800 and 1000 LT, with the wind between 1000 and 1200 LT, against the wind again between 1200 and 1500 LT, then with the wind between 1500 and 1700 LT. She then steamed at a slight angle to the wind between 1700 and 1900 LT, in a north-northwesterly (NNW) direction, then south-southwesterly (SSW) between 1900 and 2100 LT. She then exited the operations area in a northwesterly direction.

The Tai $\mathrm{He}$ is a container ship with a gross tonnage of 35963 tons. She is powered by a six-cylinder, 17 000$\mathrm{kW}$ diesel engine driving a single propeller. She has a top speed of $35 \mathrm{~km} \mathrm{~h}^{-1}$, a length of $236 \mathrm{~m}$, a beam of $32 \mathrm{~m}$, and a draft of $12 \mathrm{~m}$. During the measurement period, the Tai He was steaming in a southeasterly direction $\left(120^{\circ}\right)$ at $32 \mathrm{~km} \mathrm{~h}^{-1}$. 


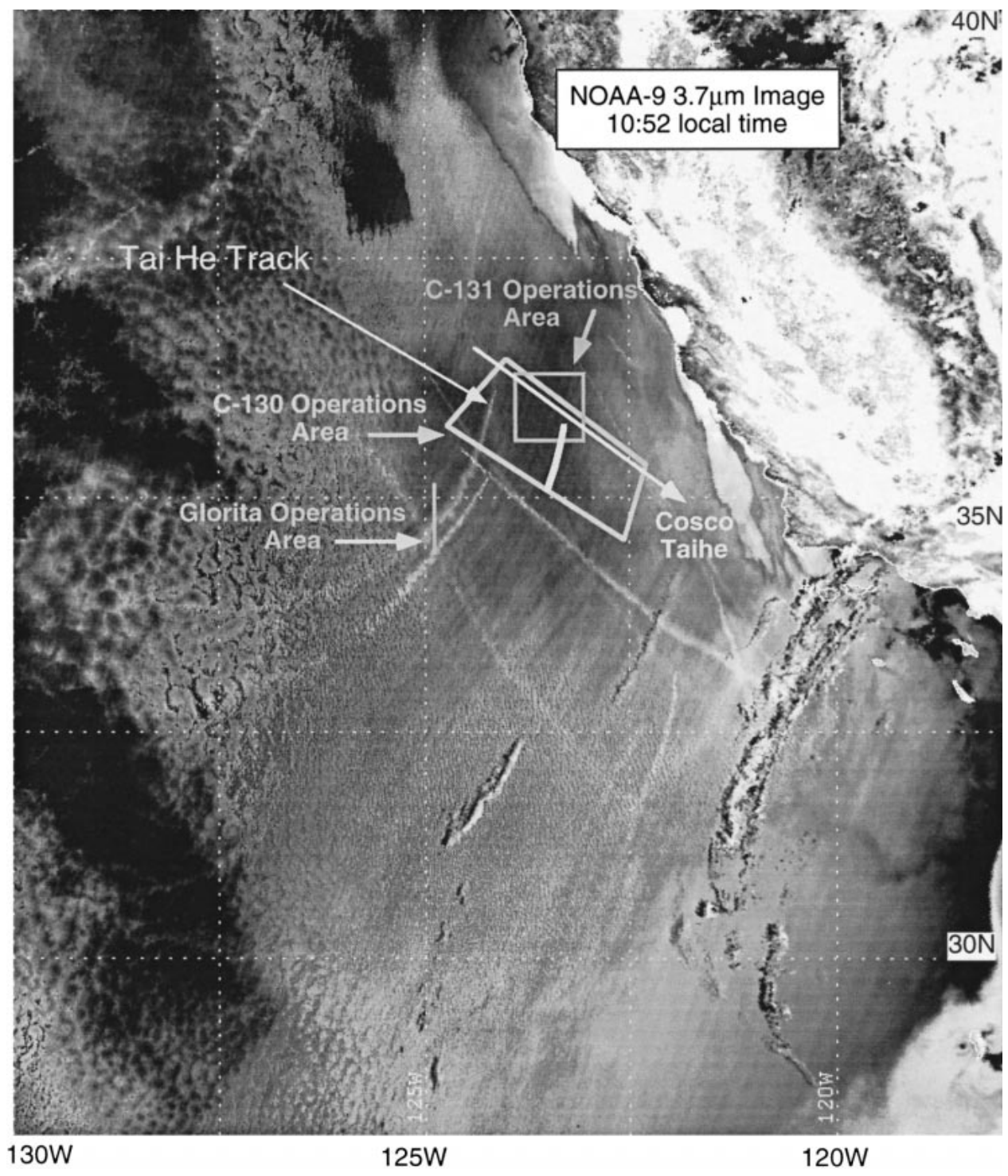

FIG. 1. NOAA-9 3.7- $\mu \mathrm{m}$ satellite image of the operations area at 1052 local time showing the eastern Pacific Ocean and California coast. The large trapezoid shows the operations area of the MRF C-130; the smaller square represents the UW C-131A operations area. The Tai He course is indicated by the thick arrow. The R/V Glorita was on a northward leg during these operations, indicated by a line parallel to $125^{\circ} \mathrm{W}$. The Tai He ship track is shown by a thin arrow.

\section{Background marine boundary layer characteristics}

\section{a. Thermodynamics and imagery}

Figure 1 is an image from the NOAA-9 polar orbiting satellite showing the operations area. The image shows channel $3(3.7 \mu \mathrm{m})$ of the AVHRR instrument on board the satellite. The coast of California appears in the upper right of the image. Monterey Bay is roughly in the center of the coastline. An extensive deck of stratocumulus clouds is apparent over the Pacific Ocean, with some clearing near the coast. The operations areas of the C-130 and C-131A and the location of the R/V Glorita are overlaid on the image. The approximate route of the Tai He as she transited the operations area is also shown on the figure.

A number of ship tracks are apparent in the image, showing that several ships were causing tracks in this air mass. The Tai He track in this image appears just within the rectangle showing the $\mathrm{C}-130$ operations area, just to the left of the square denoting the area in which the C-131A flew (the Tai He track was also present in visible imagery). By the time the aircraft arrived on station, the track had advected into the C-131A operations area.

Knowing the ship position as a function of time and 

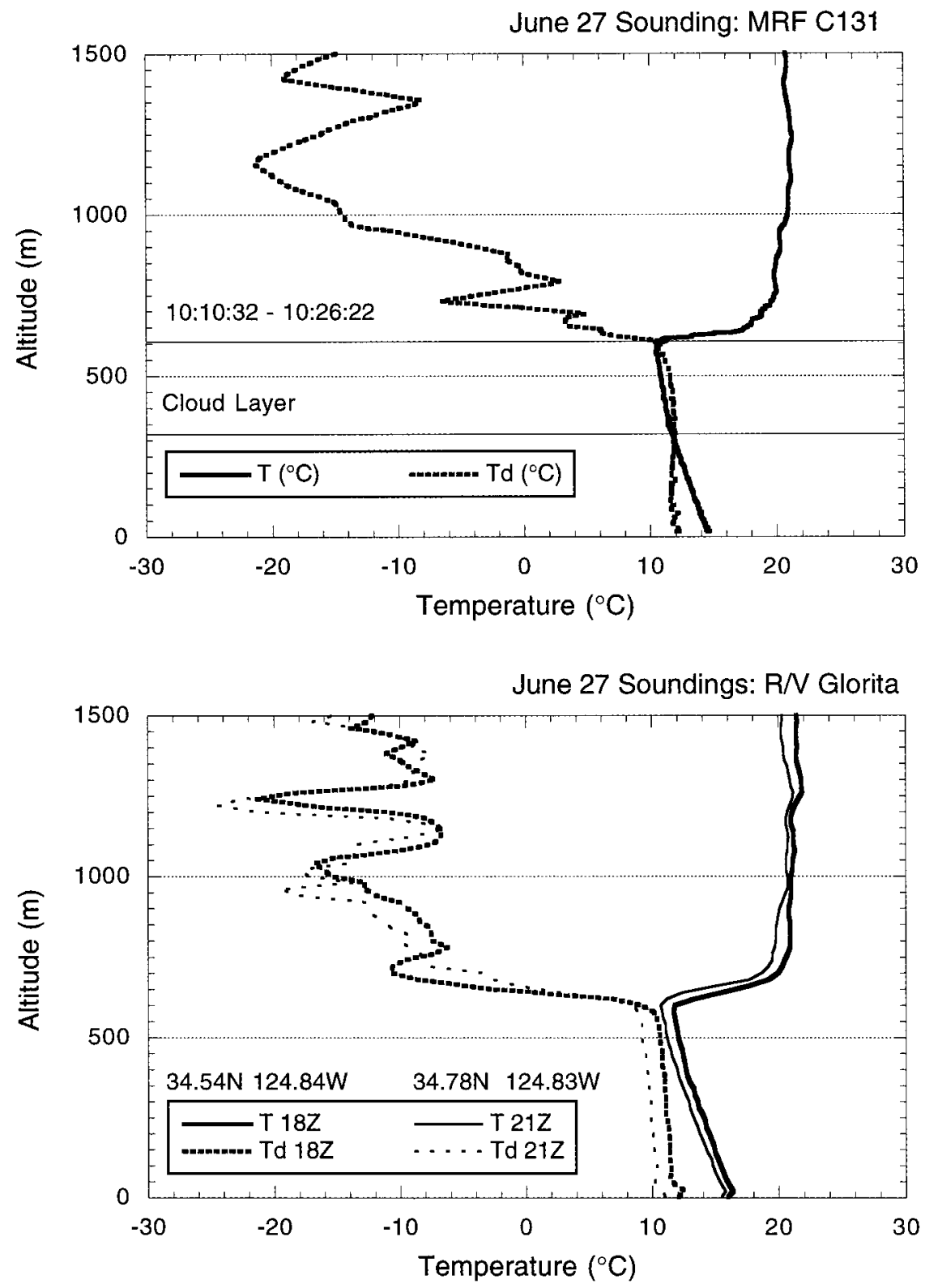

FIG. 2. Vertical profiles of temperature and dewpoint temperature. The upper panel shows a profile taken from the MRF C-130 during a descent to $30 \mathrm{~m}$. Typical cloud-base and cloud-top heights are indicated by the shaded area in the upper panel. The lower panel shows two soundings taken from the R/V Glorita, which was WSW of the aircraft operations area.

the mean wind speed and direction in the boundary layer, a Gaussian puff dispersion model (Petersen and Lavdas 1986) was used to calculate the location of the Tai He plume as a function of time starting at 1100 local time. The wind speed during the time the aircraft were in the vicinity of the Tai He varied between 10 and 20 $\mathrm{m} \mathrm{s}^{-1}$ (mean value $14 \mathrm{~m} \mathrm{~s}^{-1}$ ), and the wind direction varied from NNW to NNE in the operations area. The calculated position of the Tai He plume at 1400 (toward the end of the aircraft operations period) is shown in Fig. 1 as a heavy line starting near the southeastern corner of the C-131A operations area square. The calculated plume location corresponded extremely well with the ship track observed in the AVHRR channel-3 satellite image from $1633 \mathrm{LT}$, corroborating that the track shown in Fig. 1 originated with the Tai He.

\section{1) Temperature PROfiles}

Figure 2 shows vertical profiles of temperature and dewpoint temperature for several locations and times during the operations period. The profiles show a strong 
inversion at approximately $600 \mathrm{~m}$. Some of the aircraft profiles indicate that a slight decoupling of the boundary layer may have taken place at around $250 \mathrm{~m}$. There was a layer of dry air above the cloud deck. The inversion height increased as a function of distance from the coast. As is apparent in Fig. 1, the boundary layer was topped by an extensive deck of stratocumulus clouds. The cloud deck was typically $200 \mathrm{~m}$ thick.

\section{2) Turbulence}

The C-130 flew a pattern upwind and to the north of the Tai $\mathrm{He}$, aimed at obtaining turbulence data for the boundary layer. Heat and buoyancy fluxes were small and slightly negative below $300 \mathrm{~m}$. Both reached a maximum of $3 \mathrm{~W} \mathrm{~m}^{-2}$ at an altitude of $450 \mathrm{~m}$ and decreased toward cloud top. The Reynolds stress at the surface was $0.14 \mathrm{~Pa}$ and decreased with height. The MoninObukhov buoyancy parameter $\left(z_{i} / L\right.$, where $z_{i}$ is the boundary layer depth and $L$ is the Obukhov length) for these conditions was 0.11 , indicating that turbulence in the boundary layer was shear driven from the surface rather than buoyancy driven.

\section{b. Aerosol properties}

\section{1) THERMAL VOLATILITY DATA}

The thermal volatility of the 0.05 to 1 - $\mu$ m-radius (accumulation-mode) aerosol was characterized aboard the C-130, giving an indication of its chemical composition. The aerosol was sampled through an inlet on the C-130 via a heating system to an optical particle counter (Particle Measuring Systems ASASP-X) where they were counted and sized. This technique has been used in a number of investigations (e.g., Clarke et al. 1987; O'Dowd and Smith 1993).

A typical run with this system was to first sample the ambient aerosol and heat it to three temperatures $\left(40^{\circ}\right.$, $150^{\circ}$, and $340^{\circ} \mathrm{C}$ ) in separate steps. Sulfuric acid volatilizes at approximately $100^{\circ} \mathrm{C}$, so changes in the aerosol size distribution between $40^{\circ}$ and $150^{\circ} \mathrm{C}$ are interpreted as being due to loss of $\mathrm{H}_{2} \mathrm{SO}_{4}$. Ammonium sulfate/ bisulfate volatilizes between $150^{\circ}$ and $340^{\circ} \mathrm{C}$, and changes in the size distributions between these temperatures are interpreted as being due to the loss of these compounds. The aerosol remaining at $340^{\circ} \mathrm{C}$ is assumed to be either sea salt or elemental carbon.

There is a limitation to this technique when compounds other than sulfuric acid, partially or totally neutralized sulfate, sea salt, or soot are present in the aerosol. Organic compounds were found to have been present in the aerosol (Russell et al. 2000). The analyzed polycyclic aromatic hydrocarbon components were found in concentrations typically between 1 and $100 \mathrm{ng}$ $\mathrm{m}^{-3}$. These compounds typically have boiling points at or above $340^{\circ} \mathrm{C}$ and could therefore be interpreted as sea salt or elemental carbon with the volatility tech- nique. There may also have been other lighter-molecular weight organic compounds in the aerosol that volatilize at lower temperatures, thus potentially confounding the interpretation of the sulfuric acid/sulfate components. Since no additional information is available as to the presence or absence of such compounds in the aerosol, the following discussion will assume that they do not contribute substantially to the thermal characteristics of the aerosol. We shall see in the "Organic cloud droplet nuclei" section [in section $3 b(2)$ below], however, that carbon-containing particles played a significant role in cloud drop formation in the clouds we encountered.

Figure 3 illustrates the typical thermal volatility characteristics of the boundary layer and above-cloud aerosol. Figure 3 a shows size distributions at three temperatures sampled at $30 \mathrm{~m}$, well below cloud base in the marine boundary layer. The number size distribution of the aerosol between 0.05 and $1 \mu \mathrm{m}$ sampled at $40^{\circ} \mathrm{C}$ shows a peak at $0.08-\mu \mathrm{m}$ and a secondary peak at 0.2 $\mu \mathrm{m}$ radius. The total accumulation-mode number concentration was $138 \mathrm{~cm}^{-3}$ for this distribution. The size distribution shifted to smaller sizes upon heating to $150^{\circ} \mathrm{C}$, and the number concentration decreased to 100 $\mathrm{cm}^{-3}$. Upon heating to $340^{\circ} \mathrm{C}$, only $20-\mathrm{cm}^{-3}$ particles were left, with the major decrease in number below $0.2-$ $\mu \mathrm{m}$ radius.

The change between $40^{\circ}$ and $150^{\circ} \mathrm{C}$ is an indication of the presence of some nonneutralized sulfuric acid, perhaps even an external mixture. The largest fraction of the accumulation-mode aerosol, however, was either partially or totally neutralized sulfate. We assume here that the particles remaining at $340^{\circ} \mathrm{C}$ were sea salt. This assumption is supported to a large extent by independent single particle analysis (next section.) Comparing the $40^{\circ}$ and $340^{\circ} \mathrm{C}$ distributions, it is apparent that most of the particles larger than $0.2 \mu \mathrm{m}$ were sea salt; however, these particles only accounted for about $15 \%$ of the number of accumulation-mode aerosols. As is typical for the marine boundary layer, the number of accumulation-mode aerosol particles in this case was dominated by partially neutralized sulfate.

Figure 3b shows similar size distributions at $200 \mathrm{~m}$, near cloud base. As would be expected for a well-mixed boundary layer, the size distributions and thermal volatility characteristics of the aerosol were the same as for the sample at $30 \mathrm{~m}$. Interstitial distributions measured in cloud at $400 \mathrm{~m}$ (not shown) indicated that by number approximately $80 \%$ of the accumulation-mode particles had been taken up into cloud droplets.

Distributions for a sample taken above cloud in the free troposphere are shown in Fig. 3c. There are marked differences in the composition and concentration of the free tropospheric aerosol. On this day, the marine boundary layer was more polluted than the air aloft; the above-cloud accumulation-mode concentration was only about $40 \mathrm{~cm}^{-3}$ compared to about $120 \mathrm{~cm}^{-3}$ in the boundary layer - a factor of 3 lower. There is also little 
difference in the $40^{\circ}$ and $150^{\circ} \mathrm{C}$ distributions, indicating that the aerosol was mostly ammonium sulfate/bisulfate and probably well aged. There are particles left at $340^{\circ} \mathrm{C}$. In this case they are probably not dominated by sea salt (as discussed below in section 4.2.) Candidates for this refractory material other than sea salt include soil dust and elemental carbon or organic carbon compounds with high boiling points.

\section{2) Single Particle AnAlysis}

Single particle analysis (SPA) was carried out on samples of cloud droplet residual particles, particles in the Tai He and Mount Vernon plumes, as well as the belowand above-cloud aerosol. Particle samples were placed in a scanning electron microscope (JEOL JSM-6300) and the size, morphology, and chemical composition of the particles was determined using electron probe X-ray microanalysis techniques (Jambers et al. 1995). The lower size limit for single particle analysis was $0.1-\mu \mathrm{m}$ radius; particles below this size were not resolved. A total of 500 particles per sample were analyzed. Once particle size and composition were determined, a hierarchical cluster analysis was performed that grouped individual particles with similar compositions (Bernard et al. 1986).

Table 1 summarizes the results from the single particle analysis. The first column in the table describes the sample. The subsequent columns give the number of clusters obtained in the heirarchical cluster analysis, the percentage of particles belonging to each cluster, the mean radius of particles in the cluster, and the cluster composition.

Two samples of residual particles from droplets in the unperturbed cloud were obtained during this flight. One sample was obtained on the ferry flight out to the operations area, and the second was obtained in the operations area well away from the ships. Similar clusters were found in both samples, which accounted for most of the particles larger than $0.1 \mu \mathrm{m}$ : sea salt, particles containing organic material and chlorine, and particles containing sea salt and sulfur. The inorganic composition of the particles is consistent with the composition for the boundary layer particles larger than $0.1 \mu \mathrm{m}$ determined using the thermal volatility technique. Two other clusters were found in the sample on the ferry flight to the operations area-one containing only organic material, and the other containing sulfur, calcium, and chlorine. The additional two clusters in the ferry flight sample may have been a result of a slightly different airmass composition near the coast as opposed to offshore near the ships.

\section{Organic cloud droplet nuclei}

The clusters containing organic material or organic material plus chlorine are quite interesting. These compositions account for between $25 \%$ and $36 \%$ of the cloud
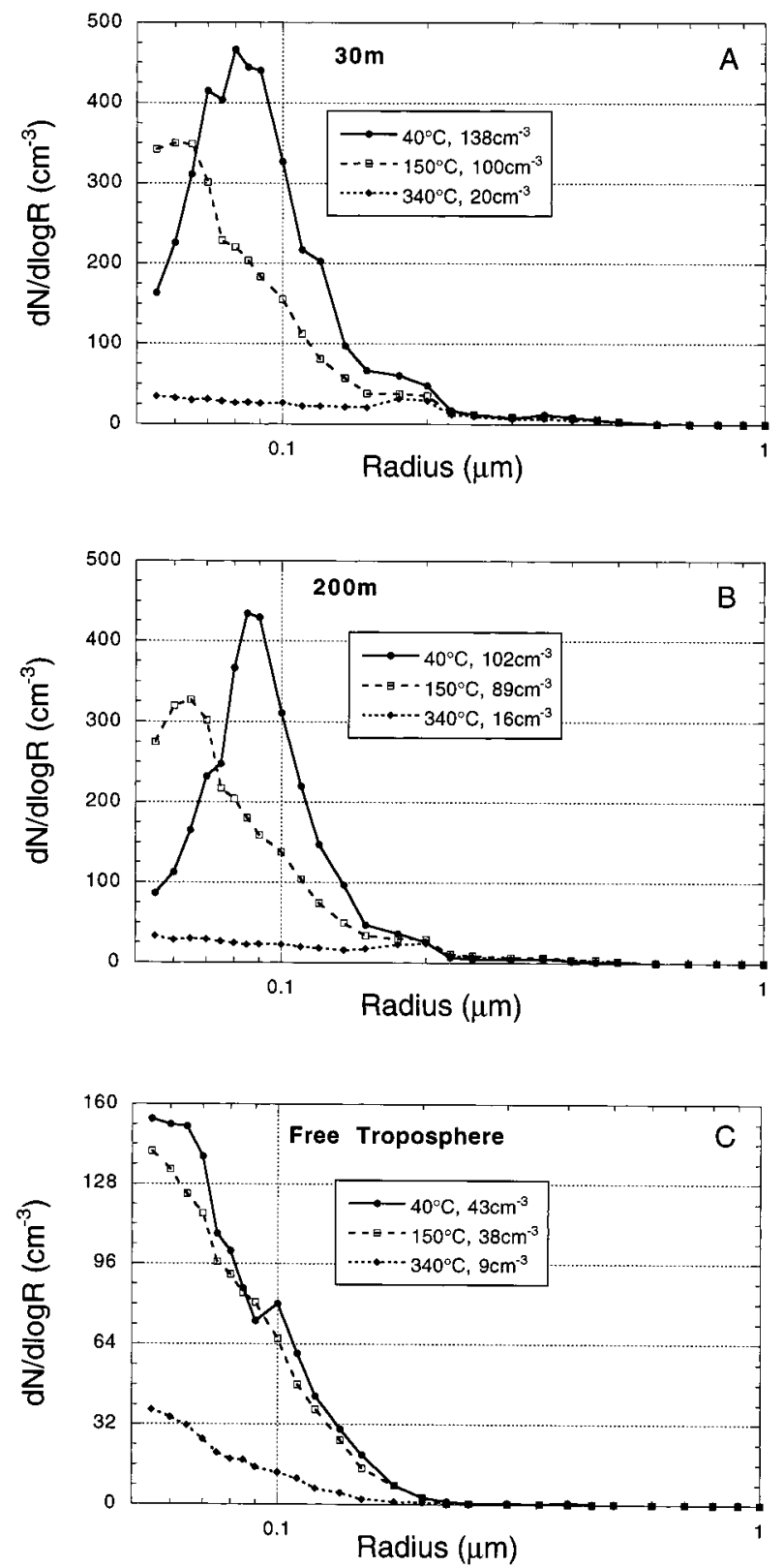

FIG. 3. Aerosol size distributions from the aerosol thermal volatility instrument. Size distributions for particles after heating to $40^{\circ}, 150^{\circ}$, and $340^{\circ} \mathrm{C}$ are shown in (a)-(c). (a) and (b) show distributions in the boundary layer below cloud. (c) shows distributions taken in freetropospheric air.

droplet residual particles larger than $0.1 \mu \mathrm{m}$ in the two ambient cloud samples. The fact that organic material alone was found in many of the particles indicates that the organic material was not associated with other aerosol particles (i.e., as a coating). The organic plus chlorine cluster is also intriguing. This cluster may represent a combination of organic material and sea salt. If this were the case, however, sodium should also be present in the cluster, unless the amount of sea salt in the particles was very small. Examination of individual spectra 
TABLE 1. Summary of the single particle analysis results for 27 Jun 1994. 500 particles were analyzed per sample. Heirarchical cluster analysis was used to group particles according to their composition.

\begin{tabular}{|c|c|c|c|c|}
\hline Sample & Cluster & $\%$ of total & Mean radius & Composition \\
\hline Ambient cloud residuals: ferry out & $\begin{array}{l}1 \\
2 \\
3 \\
4 \\
5\end{array}$ & $\begin{array}{r}43.0 \\
25.0 \\
19.4 \\
11.4 \\
1.2\end{array}$ & $\begin{array}{l}0.2 \\
0.25 \\
0.25 \\
0.2 \\
0.15\end{array}$ & $\begin{array}{l}\mathrm{Cl}, \mathrm{Na} \\
\mathrm{Cl}, \text { Org. } \\
\mathrm{Cl}, \mathrm{S}, \mathrm{Na} \\
\text { Org. } \\
\text { S, Ca, Cl }\end{array}$ \\
\hline Ambient cloud residuals: far from ships & $\begin{array}{l}1 \\
2 \\
3\end{array}$ & $\begin{array}{l}41.8 \\
32.8 \\
25.4\end{array}$ & $\begin{array}{l}0.2 \\
0.2 \\
0.2\end{array}$ & $\begin{array}{l}\mathrm{Cl}, \mathrm{Na} \\
\mathrm{Cl}, \mathrm{S}, \mathrm{Na} \\
\mathrm{Cl}, \text { Org. }\end{array}$ \\
\hline Ship track residuals: Tai $\mathrm{He}$ & $\begin{array}{l}1 \\
2 \\
3\end{array}$ & $\begin{array}{l}46.8 \\
41.0 \\
12.2\end{array}$ & $\begin{array}{l}0.2 \\
0.2 \\
0.2\end{array}$ & $\begin{array}{l}\mathrm{Cl}, \mathrm{S}, \mathrm{Na} \\
\mathrm{Cl}, \mathrm{Na} \\
\mathrm{Cl}, \text { Org. }\end{array}$ \\
\hline In-cloud plume residuals: Mount Vernon & $\begin{array}{l}1 \\
2 \\
3 \\
4\end{array}$ & $\begin{array}{r}44.3 \\
25.9 \\
21.2 \\
8.5\end{array}$ & $\begin{array}{l}0.2 \\
0.2 \\
0.2 \\
0.15\end{array}$ & $\begin{array}{l}\mathrm{Cl}, \mathrm{Na} \\
\mathrm{Cl}, \mathrm{S}, \mathrm{Ca}, \mathrm{Na} \\
\mathrm{Cl}, \text { Org. } \\
\mathrm{S}, \mathrm{Ca},(\mathrm{Na}, \mathrm{Cl})\end{array}$ \\
\hline Tai He plume: below cloud & $\begin{array}{l}1 \\
2 \\
3 \\
4\end{array}$ & $\begin{array}{r}54.5 \\
25.4 \\
12.5 \\
7.7\end{array}$ & $\begin{array}{l}0.25 \\
0.2 \\
0.2 \\
0.25\end{array}$ & $\begin{array}{l}\mathrm{Cl}, \mathrm{Na} \\
\mathrm{Cl}, \mathrm{S}, \mathrm{Na} \\
\mathrm{S}, \mathrm{Ca}, \mathrm{Cl}, \mathrm{Na}) \\
\text { Si, Org. }\end{array}$ \\
\hline Mount Vernon plume: below cloud & $\begin{array}{l}1 \\
2 \\
3\end{array}$ & $\begin{array}{r}60.6 \\
32.2 \\
7.2\end{array}$ & $\begin{array}{l}0.25 \\
0.3 \\
0.25\end{array}$ & $\begin{array}{l}\mathrm{Cl}, \mathrm{Na} \\
\mathrm{Cl}, \mathrm{S}, \mathrm{Na} \\
\mathrm{Cl}, \mathrm{S}, \mathrm{Ca}, \mathrm{Na}\end{array}$ \\
\hline Ambient below-cloud aerosol: near Tai He & $\begin{array}{l}1 \\
2 \\
3 \\
4 \\
5\end{array}$ & $\begin{array}{r}50.4 \\
19.0 \\
19.0 \\
10.2 \\
1.4\end{array}$ & $\begin{array}{l}0.25 \\
0.25 \\
0.3 \\
0.25 \\
0.4\end{array}$ & $\begin{array}{l}\mathrm{Cl}, \mathrm{Na} \\
\mathrm{Cl}, \mathrm{S}, \mathrm{Na} \\
\mathrm{Cl}, \mathrm{Na}, \mathrm{S},(\mathrm{Mg}) \\
\mathrm{Cl}, \mathrm{S}, \mathrm{Ca}, \mathrm{Na} \\
\mathrm{S}, \mathrm{Si}, \mathrm{Al}\end{array}$ \\
\hline Above-cloud aerosol: ferry back & $\begin{array}{l}1 \\
2 \\
3 \\
4 \\
5\end{array}$ & $\begin{array}{r}33.9 \\
23.6 \\
13.4 \\
11.0 \\
9.4\end{array}$ & $\begin{array}{l}0.45 \\
0.35 \\
0.15 \\
0.2 \\
0.15\end{array}$ & $\begin{array}{l}\mathrm{Si}, \mathrm{Al}, \mathrm{Fe} \\
\text { Org. } \\
\mathrm{S}, \mathrm{Org} . \\
\mathrm{Cl}, \mathrm{Na} \\
\mathrm{Cl}, \mathrm{K}, \mathrm{S}\end{array}$ \\
\hline
\end{tabular}

show that in most cases the $\mathrm{C} 1$ peak was quite large, while no sodium peak was detectable. This would not likely be the case if the $\mathrm{C} 1$ were found in sea salt.

A number of polycyclic aromatic hydrocarbons were found in the residual particles from this day (Russell et al. 2000). These types of compounds are associated with combustion processes and are an indication that the boundary layer was influenced by continental emissions. Coupled with the single particle analysis results, we see that cloud droplets were forming on organic material.

We can estimate a lower limit for the number of cloud droplets in these clouds that formed on organic particles by combining the single particle results with residual particle microphysical measurements. In ambient clouds on this day, typically $25 \%$ of the accumulation-mode residual particles were larger than $0.1 \mu \mathrm{m}$, the lower detection size for the SPA. Between $25 \%$ and $36 \%$ of these particles were organic in nature, giving the result that $6 \%-9 \%$ of the droplets in these clouds formed on organic aerosol particles. This is an underestimate, since there may well have been organic particles below the detection size of both the SPA and the optical particle counter used to count and size the residual particles.

\section{3) BulK CHEMiCAL COMPOSITION}

Table 2 summarizes the bulk chemical composition of the boundary layer aerosol. Both below-cloud and in-cloud interstitial samples were taken in and outside ship plumes. No clear differences in any of the ionic species can be seen between the plume and ambient aerosol samples. This is not particularly surprising, since even relatively large changes in number concentrations of particles smaller than $0.1 \mu \mathrm{m}$ may not necessarily be reflected in differences in particle mass. Sea salt (sodium and chloride) was the largest fraction of the sub-3.5$\mu \mathrm{m}$ aerosol mass; the combination amounted to $2.7 \mu \mathrm{g}$ $\mathrm{m}^{-3}$ in the ambient below-cloud aerosol. Non-sea salt sulfate contributed $0.5 \mu \mathrm{g} \mathrm{m}^{-3}$, while nitrate and ammonium contributed 0.19 and $0.16 \mu \mathrm{g} \mathrm{m}^{-3}$, respectively.

The sum of the major ion mass in the ambient belowcloud ( $<1.75-\mu \mathrm{m}$ radius) sample was $3.6 \mu \mathrm{g} \mathrm{m}^{-3}$. We can also estimate the boundary layer aerosol mass by integrating the volume distributions obtained with the thermal volatility instrument on the C-130 and the CVI on the C-131A (when used as an aerosol inlet). Using measured dry aerosol $\left(40^{\circ} \mathrm{C}\right)$ volume distributions and assuming a particle density of $1.77 \mathrm{~g} \mathrm{~cm}^{-3}$ (ammonium 
TABLE 2. Summary of the bulk ionic chemical composition of the boundary layer aerosol (units are $\mu \mathrm{g} \mathrm{m}^{-3}$ ). Two separate filter samples were analyzed by ion chromatography: one for total aerosol (whole air inlet: particles + droplets in cloud) and one for particles smaller than $1.75-\mu \mathrm{m}$ radius (interstitial inlet). Samples were taken on board the C-131A and analyzed after the experiment at the University of Washington.

\begin{tabular}{|c|c|c|c|c|c|}
\hline Sample/Ion & $\mathrm{Cl}^{-}$ & $\mathrm{Na}^{+}$ & $\mathrm{nss}-\mathrm{SO}_{4}=$ & $\mathrm{NO}_{3}^{-}$ & $\mathrm{NH}_{4}{ }^{+}$ \\
\hline \multicolumn{6}{|c|}{ Tai He track (interstitial) } \\
\hline$<1.75 \mu \mathrm{m}$ & 0.06 & 0.04 & 0.04 & 0.06 & 0.01 \\
\hline Total & 0.04 & 0.03 & 0.01 & 0.05 & 0.02 \\
\hline \multicolumn{6}{|c|}{ Ambient (interstitial) } \\
\hline$<1.75 \mu \mathrm{m}$ & 0.22 & 0.11 & - & 0.07 & 0.01 \\
\hline Total & 0.07 & 0.01 & 0.03 & 0.03 & 0.02 \\
\hline \multicolumn{6}{|c|}{ Tai He plume (below cloud) } \\
\hline$<1.75 \mu \mathrm{m}$ & 1.4 & 0.88 & 0.5 & 0.27 & 0.50 \\
\hline Total & 1.59 & - & 0.65 & 0.16 & - \\
\hline \multicolumn{6}{|c|}{ Ambient (below cloud) } \\
\hline$<1.75 \mu \mathrm{m}$ & 1.61 & 1.05 & 0.54 & 0.19 & 0.16 \\
\hline Total & 1.76 & 1.10 & 0.59 & 0.15 & 0.16 \\
\hline \multicolumn{6}{|c|}{ Mt. Vernon plume (below cloud) } \\
\hline$<1.75 \mu \mathrm{m}$ & 1.49 & 0.89 & 0.76 & 0.17 & 0.32 \\
\hline Total & 1.57 & 1.01 & 0.66 & 0.19 & 0.34 \\
\hline
\end{tabular}

sulfate), we obtain values between 1 and $20 \mu \mathrm{g} \mathrm{m}^{-3}$, depending on time and location in the boundary layer. Some of the variation in the mass estimated from the thermal volatility technique and CVI may have been due to inlet effects; neither inlet was optimized to collect particle mass.

\section{4) CNN SPECTRA}

Table 3 is a summary of the cloud condensation nuclei measurements made using the Desert Research Institute (DRI) CCN spectrometer (Hudson 1989) in the background marine boundary layer below cloud. The average CCN/CN ratio for the eight samples was 0.3 (std dev $=0.08$ - roughly one-third of the $\mathrm{CCN}$ in the boundary layer were active as $\mathrm{CCN}$ at $1 \%$ supersaturation. The average boundary layer CCN concentration of $368 \mathrm{~cm}^{-3}$ ( std dev $=123$ ) is a bit more than double the typical cloud droplet concentration in the ambient clouds (about $150 \mathrm{~cm}^{-3}$ - see Table 5.) The CCN values reported here are similar to previous observations made off the southern California coast (Hudson and Frisbie 1991). No CN data for the ship plumes are given in Table 3 since the particle counter used in the DRI CCN payload was not able to measure the extremely high $\mathrm{CN}$ concentrations in the plumes in the immediate vicinity of the ships.

The empirical power-law relation $N_{\mathrm{CCN}}=C S^{K}$ is often used to predict the number concentration of $\mathrm{CCN}\left[N_{\mathrm{CCN}}\right.$ $\left.\left(\mathrm{cm}^{-3}\right)\right]$ active at a given supersaturation $(S$, percent $)$, where $C$ and $K$ are constants that depend on air mass type. It has been observed that the exponent $K$ is not a constant over a large range of $S$; rather, it depends on the range of $S$ values over which the slope is calculated. Values of $K$ are given for three different $S$ ranges.

The CCN concentrations in the ship plumes were all
TABLE 3. Summary of CCN measurements made in the background marine boundary layer and in ship plumes using the DRI CCN spectrometer. $\mathrm{CN}$ are particles larger than $0.01-\mu \mathrm{m}$ radius; $\mathrm{CCN}$ are particles active at $1 \%$ supersaturation; MDSc is the median supersaturation for the spectrum; $K$ is the exponent in the equation $N=C S^{K}$ given for three different $S$ ranges. M denotes a plume sample from the Mount Vernon and T denotes a sample from the Tai He plume.

\begin{tabular}{|c|c|c|c|c|c|c|}
\hline \multirow[b]{2}{*}{ Local time } & \multirow[b]{2}{*}{$\begin{array}{c}\mathrm{CN} \\
\left(\mathrm{cm}^{-3}\right)\end{array}$} & \multirow[b]{2}{*}{$\begin{array}{c}\mathrm{CCN} \\
\left(\mathrm{cm}^{-3}\right)\end{array}$} & \multirow[b]{2}{*}{$\begin{array}{c}\text { MDSc } \\
(\%)\end{array}$} & \multicolumn{3}{|c|}{$K$} \\
\hline & & & & $\begin{array}{l}0.04 \\
-0.1\end{array}$ & $\begin{array}{c}0.1 \\
-0.4\end{array}$ & $\begin{array}{c}0.4 \\
-1.0\end{array}$ \\
\hline \multicolumn{7}{|c|}{ Background } \\
\hline $1204: 27-1205: 30$ & 750 & 116 & 0.39 & 1.1 & 0.56 & 0.29 \\
\hline $1327: 00-1329: 00$ & 1030 & 283 & 0.30 & 1.2 & 0.40 & 0.23 \\
\hline $1341: 24-1343: 07$ & 1500 & 395 & 0.30 & 1.2 & 0.53 & 0.30 \\
\hline $1351: 40-1352: 30$ & 1560 & 484 & 0.30 & 1.1 & 0.45 & 0.24 \\
\hline $1412: 00-1414: 40$ & 1380 & 353 & 0.24 & 1.2 & 0.42 & 0.24 \\
\hline 1426:01-1427:59 & 1110 & 443 & 0.30 & 1.0 & 0.36 & 0.24 \\
\hline $1431: 16-1431: 46$ & 1020 & 379 & 0.24 & 1.1 & 0.41 & 0.23 \\
\hline $1435: 31-1436: 43$ & 1630 & 491 & 0.30 & 1.1 & 0.41 & 0.27 \\
\hline \multicolumn{7}{|c|}{ Plume } \\
\hline Т 1329:54-1330:07 & & 1124 & 0.39 & 1.3 & 0.68 & 0.25 \\
\hline Т 1338:17-1338:26 & & 2149 & 0.39 & 1.4 & 0.74 & 0.39 \\
\hline Т 1351:19-1551:25 & & 2052 & 0.51 & 1.0 & 0.86 & 0.39 \\
\hline M 1419:10-1419:20 & & 671 & 0.39 & 1.2 & 0.50 & 0.34 \\
\hline M 1421:07-1421:14 & & 2002 & 0.51 & 1.3 & 0.61 & 0.51 \\
\hline M 1433:35-1433:42 & & 812 & 0.39 & 1.2 & 0.58 & 0.30 \\
\hline M 1434:54-1434:58 & & 538 & 0.39 & 1.1 & 0.50 & 0.33 \\
\hline M 1443:21-1443:30 & & 607 & 0.39 & 1.2 & 0.55 & 0.32 \\
\hline
\end{tabular}

well above background values (significance levels: Tai He-background, 99.99\%; Mount Vernon-background, 98.7\%; Tai He-Mount Vernon: 95.06\%). CCN concentrations (at 1\% supersaturation) in the Tai He plume were a factor of 5 higher than in the background boundary layer, while values in the Mount Vernon plume were typically between 2 and 2.5 times greater, but at times not much higher than background values. A detailed description of ship emissions is given in Hobbs et al. (2000); in this particular case it is clear that while both ships were producing particles active at $1 \%$ supersaturation, the Tai He CCN source strength was more than double that of the Mount Vernon.

\section{5) Particle scavenging}

The fraction of aerosol material scavenged into clouds is of interest from several points of view. From the aerosol perspective, only the fraction of the aerosol scavenged into cloud droplets will be subject to modification by aqueous-phase reactions in cloud water. Measurements have shown that the aerosol size spectrum can be substantially modified by aqueous-phase processes (Hoppel et al. 1994, 1986; Noone et al. 1992). Nucleation scavenging has been shown to be the primary process for transferring aerosol material into cloud droplets (Flossmann et al. 1985; Noone et al. 1992). The nucleation step will thus control the initial chemical composition of the cloud water, and to a large degree the extent to which reactions can occur. Since the chemical composition and concentration of cloud water are 
TABLE 4. Scavenging fraction for various aerosol components. Mass scavenging fractions were computed using ambient interstitial and ambient below-cloud samples from the UW C-131 interstitial $\left(<1.75-\mu \mathrm{m}\right.$ radius) inlet (except $\mathrm{nss}-\mathrm{SO}_{4}{ }^{=}$, for which the whole-air inlet data were used.) Here, $\mathrm{N}_{\mathrm{acc}}$ denotes accumulation-mode aerosol number and was calculated from UMIST size distributions obtained on the MRF C-130.

\begin{tabular}{lc}
\hline \hline \multicolumn{1}{c}{ Property } & Scavenged fraction \\
\hline $\mathrm{Cl}^{-}$mass & 0.86 \\
$\mathrm{Na}^{+}$mass & 0.89 \\
$\mathrm{nss}^{-\mathrm{SO}_{4}{ }^{-} * \text { mass }}$ & 0.95 \\
$\mathrm{NO}_{3}{ }^{-}$mass & 0.63 \\
$\mathrm{NH}_{4}^{+}$mass & 0.97 \\
$\mathrm{~N}_{\text {acc }}$ & 0.77 \\
\hline
\end{tabular}

mass-dependent parameters, mass scavenging efficiencies are of interest in this context. In the context of ship track formation, it will be less likely that an injection of additional particles will lead to the production of a substantial number of new cloud droplets if there is already an overabundance of aerosol particles on which cloud droplets can form in the boundary layer.

Table 4 shows the mass scavenging efficiency of the various major ionic components of the aerosol. Mass scavenging efficiencies for sea salt were close to $90 \%$, while non-sea salt sulfate was $95 \%$ scavenged into cloud droplets. The estimates were made from the data presented in Table 2. In addition, the scavenging efficiency for accumulation-mode aerosol number is given in Table 4 . The value of $77 \%$ was calculated from thermal volatility measurements made at $400 \mathrm{~m}$ (just below cloud base) and from cloud interstitial aerosol measurements. The observation that a large fraction of both the accumulation-mode number and mass was taken up into cloud droplets in the background clouds indicates that an additional source of particles in this size range may possibly have an effect on cloud microphysical properties.

\section{Ship track-ambient cloud comparisons}

a. Tai He

\section{1) Transects}

Several transects were flown through the Tai He ship track. Summary data for five of the transects are presented in Table 5. We shall discuss two transects in detail to illustrate the typical changes in cloud and aerosol properties between the ship track and the ambient cloud.

Three transects were flown with the UW C-131A flying in cloud and the MRF C-130 flying above the $\mathrm{C}-131 \mathrm{~A}$. The objective was to have in situ measurements of cloud and aerosol properties using instruments on the C-131A with simultaneous measurements of the cloud radiative properties using downward-looking radiometers on board the C-130 (two Eppley pyranometers measuring broadband hemispherical irradiances: one between 0.3 and $0.7 \mu \mathrm{m}$, the other between 0.7 and
$3.0 \mu \mathrm{m})$. It should be noted that the two aircraft were flying parallel to each other, but with a slight horizontal offset during these transects. While in flight, ship plumes and tracks were identified by rapid increases and decreases in total aerosol particle number concentrations. For the purposes of postflight analysis, track edges were determined by examination of the time series of the UW TSI 3760 particle counter. The midpoint of the particle increase or decrease was identified, and a minimum of $5 \mathrm{~s}$ of data on either side of the midpoint was excluded in order to assure that averages properly reflected the track and out-of-track conditions.

There are a few facts to note when interpreting the time series plots for the transects. The TSI particle counter aboard the C-131A had a 5-s time lag with respect to the wing-mounted instruments (e.g., FSSP, PCASP, PVM-100). This lag has not been removed in the time series plots. Due to possible sampling artifacts due to intermittent droplet shattering using wing-mounted PCASP measurements for these aircraft, we will focus on the relative concentration differences between the ship track and the ambient cloud. We will not draw any conclusions based on the absolute number from the PCASP measurements for these in-cloud transects.

We shall compare the differences between the ship track and ambient cloud in terms of several parameters: droplet number, cloud liquid water content, accumulation-mode aerosol concentration, total aerosol concentration, and droplet effective radius. These comparisons are summarized in Table 5. The table includes the mean value, standard deviation, and number of observations for each of the parameters in the five transects. Effective radius values were calculated from the average drop size distributions. The final column in the table gives the ship track/ambient cloud ratio for each of the parameters. Mean values for the ship track were taken over periods well away from the track edges to obtain a representative "track" average. Ambient cloud averages were taken for equal periods (with one exception where the ambient cloud average was for a shorter period) well away from the track. In the following discussions, statistically significant differences are all taken at the $95 \%$ confidence level.

\section{(i) Transect-3 time series}

The time series for transect 3 is shown in Fig. 4. The Tai He plume was encountered at the end of the time series and is apparent as the broad peak in the particle measurements (Figs. 4d,e). Plume advection calculations confirm that the peak in particle concentration between roughly 1236 and 1237 LT was the Tai He plume, 60-70 min old and approximately $3.5 \mathrm{~km}$ wide. Clear increases in total particle number, accumulation-mode particle number, droplet concentration, and liquid water content in the ship track can be observed in this transect. A significant increase of $27 \%$ in droplet number was observed in this transect. Liquid water content also in- 


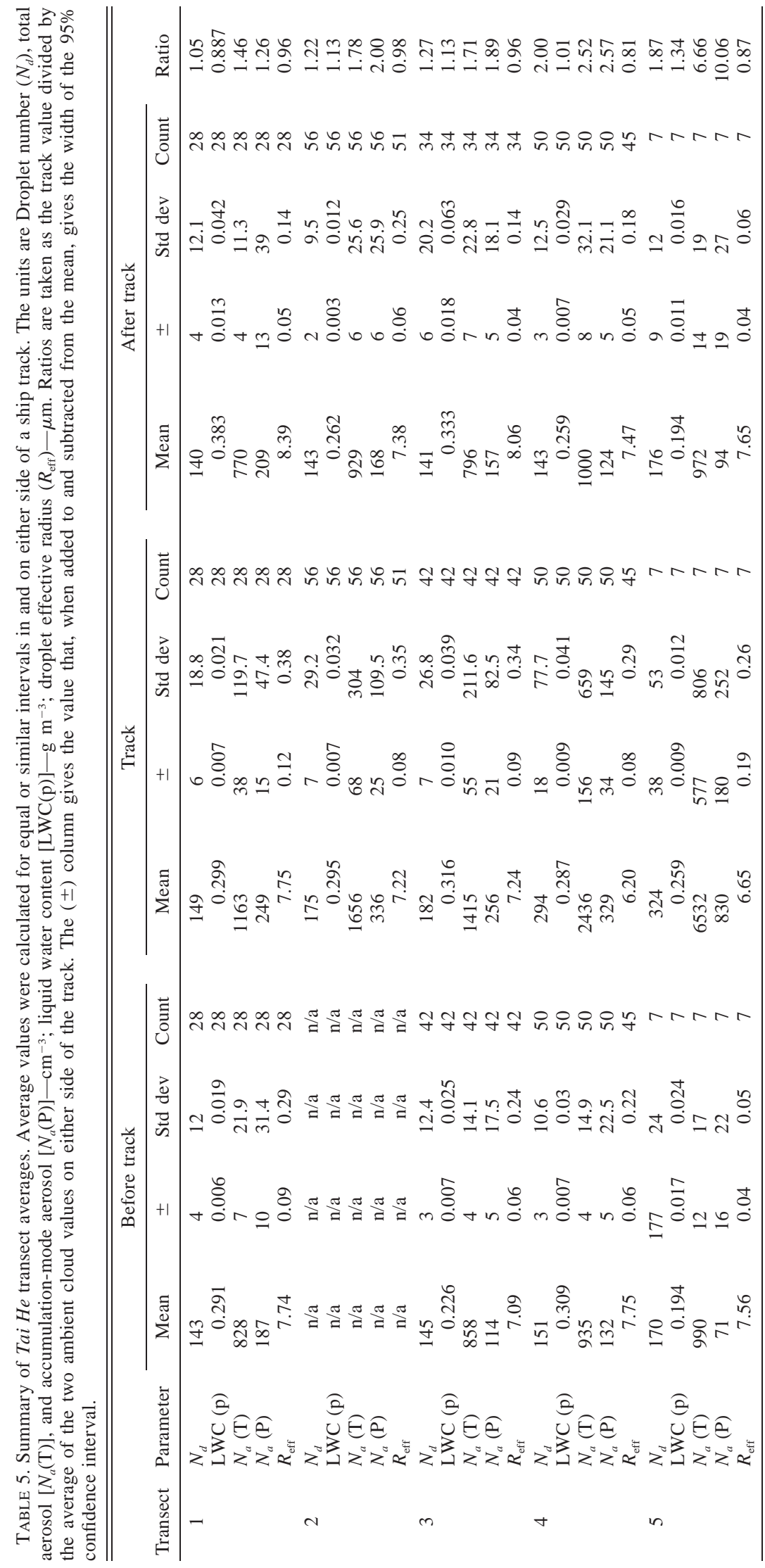



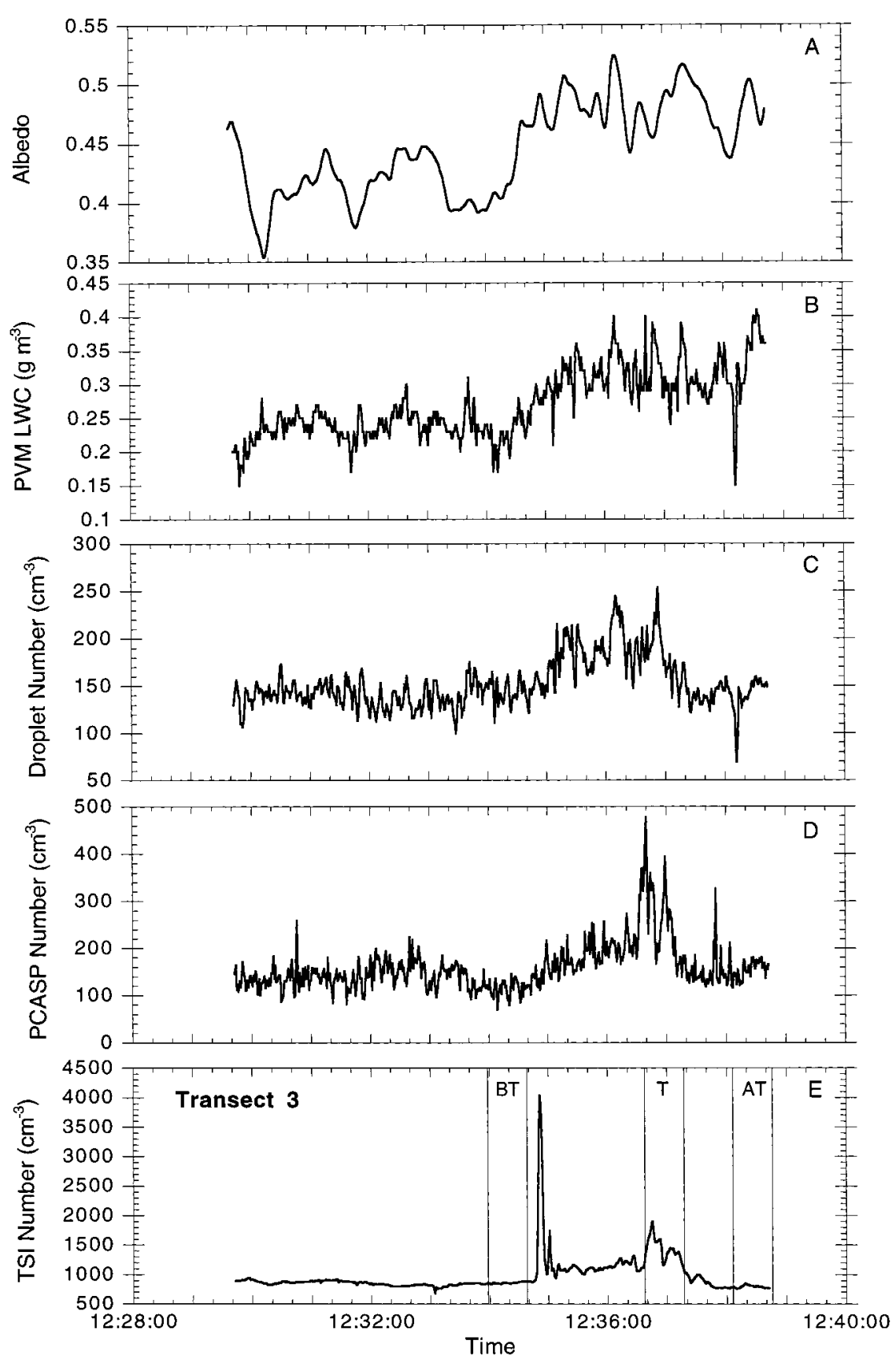

FIG. 4. Time series for transect 3 of the Tai He ship track. For these transects, the UW C-131A was flying in cloud, while the MRF C-130 was flying a vertically stacked pattern above the cloud deck. Albedo measurements were made from the MRF C-130, while the data shown in (b)-(e) came from instruments on the UW C-131A. The star in (e) indicates the time at which an interstitial aerosol size distribution sample was taken.

creased by $13 \%$ but remained elevated even when particle and droplet concentrations decreased at the edge of the ship track. As in the first two transects, droplet effective radius was larger in the ambient cloud after the ship track, but no track-ambient cloud differences were observed.

An increase in cloud albedo of $14 \%$ was observed in this case collocated with increases in particle and droplet concentrations and liquid water content (LWC) in this transect. The average visible albedo in the ambient clouds just before the ship track was 0.42 (std dev $=0.023, n=$ 299), while the average albedo in the ship track was 0.48 ( std dev $=0.018, n=42$ ). In the second transect we observed an albedo increase that was broader than the 

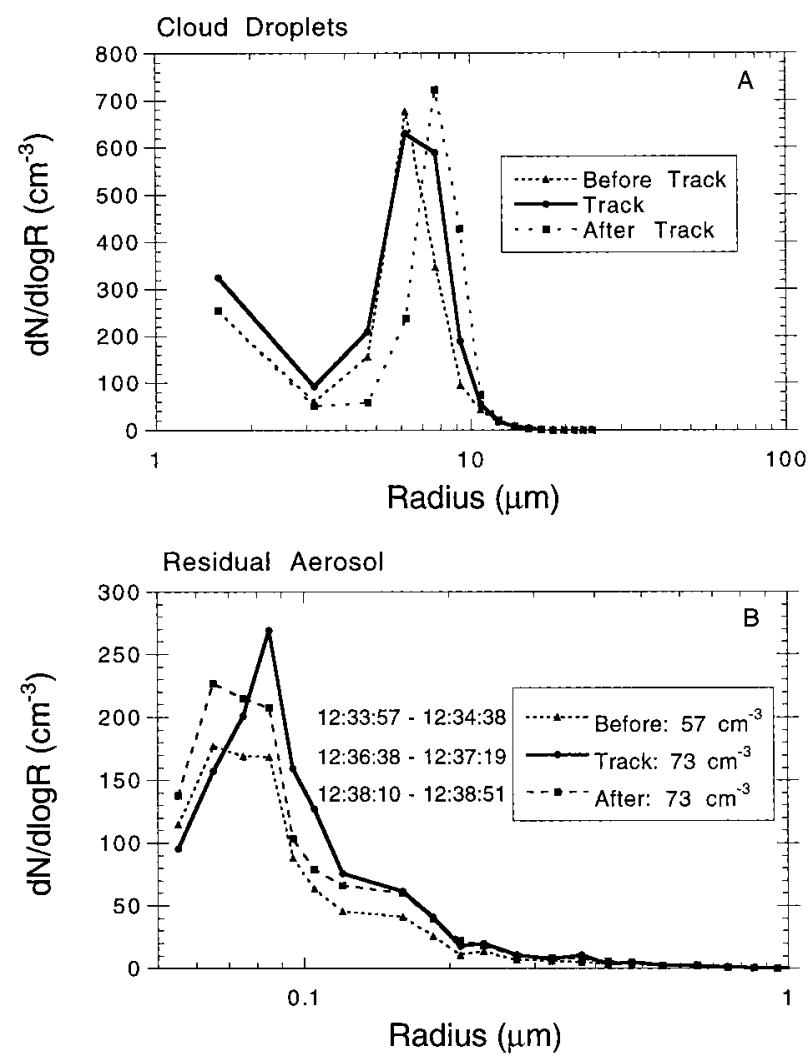

FIG. 5. Cloud and aerosol properties in transect 3 of the Tai He ship track. (a) shows cloud droplet size distributions for equal time intervals before, in, and after the ship track. (b) shows cloud droplet residual particle distributions for the corresponding periods.

observed microphysical changes in the cloud. The spatial scale of the albedo change in transect 3 is similar to the one observed in transect 2 , while the spatial scales of the ship track itself changed somewhat between transects.

Cloud and aerosol properties. Drop size distributions before, in, and after the ship track are shown in Fig. 5a. As in the previous two transects, the distributions are quite similar. The variation in the ambient cloud distributions appears to be similar in magnitude to the variations between the ship track and ambient cloud. Residual size distributions are shown in Fig. 5b. The residual particle size distributions were measured using a PMS PCASP-X optical particle counter, which was calibrated prior to the experiment (Öström et al. 2000). As in the previous two transects, there was a slight increase in mode size for the residual particles in the ship track, though no marked changes in residual particle concentrations were observed between the track and background clouds. Interstitial aerosol size distributions were not available for this transect.

\section{(ii) Transect-4 time series}

Figure 6 shows another transect of the Tai He track at 1309 LT when the track was about 50 min old and approximately $4 \mathrm{~km}$ wide. The differences in droplet and aerosol particle concentrations are more pronounced here than in the previous transects. Droplet number increased by a factor of 2 in the track, while total and accumulation-mode particle concentrations were a factor of 2.5 larger. Liquid water content showed a general decrease across the transect from $0.31 \mathrm{~g} \mathrm{~m}^{-3}$ at the start to $0.26 \mathrm{~g} \mathrm{~m}^{-3}$ at the end. In this case, there was a clear decrease in droplet effective radius compared with the ambient cloud on either side of the track. The effective radius decreased by $1.4 \mu \mathrm{m}(19 \%)$ in the track compared with the average for the ambient cloud samples. No corresponding albedo measurements are available for this transect, since the $\mathrm{C}-130$ and the $\mathrm{C}-131 \mathrm{~A}$ were no longer flying in formation at this time.

Cloud and aerosol properties. In contrast to the first three transects, there were marked changes in drop size distributions in this transect. Figure 7a shows average drop size distributions before, in, and after the track. The track droplet size distribution shows a shift of the mode toward smaller sizes shows a dramatic increase in the number of drops smaller than $7 \mu \mathrm{m}$. This combination of decrease in drop size and increase in drop number is similar to previous observations in ship tracks (King et al. 1993; Radke et al. 1989). Figure 7b shows the corresponding residual particle size distributions for the transect. In this case, little change in the shape of the distribution is seen across the track. There is an increase in residual particle number in the track but no marked shift in size of the mode of the distribution. Interestingly, here there is a large change in the drop size distribution and little change in the residual distribution, while in the previous transects little change was observed in the drop distributions and an increase in mode size was seen for the residual particles. There are two possibilities for this relative lack of variation in the residual distributions. One is that due to the shift to smaller sizes of the droplet distribution, a larger fraction of the drops were below the cut size of the CVI, and thus the residual particles in these droplets would not have been seen in the CVI. A second possibility is that the additional droplets in the track formed to a large extent on particles smaller than $0.055 \mu \mathrm{m}$. The latter scenario is supported by observations of the interstitial aerosol size distributions. Figure 7c shows interstitial size distributions for the transect. While there is variation in the background, the track distribution shows a substantial increase in the number of particles between 0.02 and $0.1 \mu \mathrm{m}$. The greatest fractional increase for particles in this range was at about $0.06 \mu \mathrm{m}$. The Tai $H e$ was thus emitting substantial numbers of particles large enough to have served as cloud droplet nuclei.

\section{2) General discussion of the TaI HE TRANSECTS}

Five transects were flown through the Tai He track. Clear increases in total aerosol were observed in all 


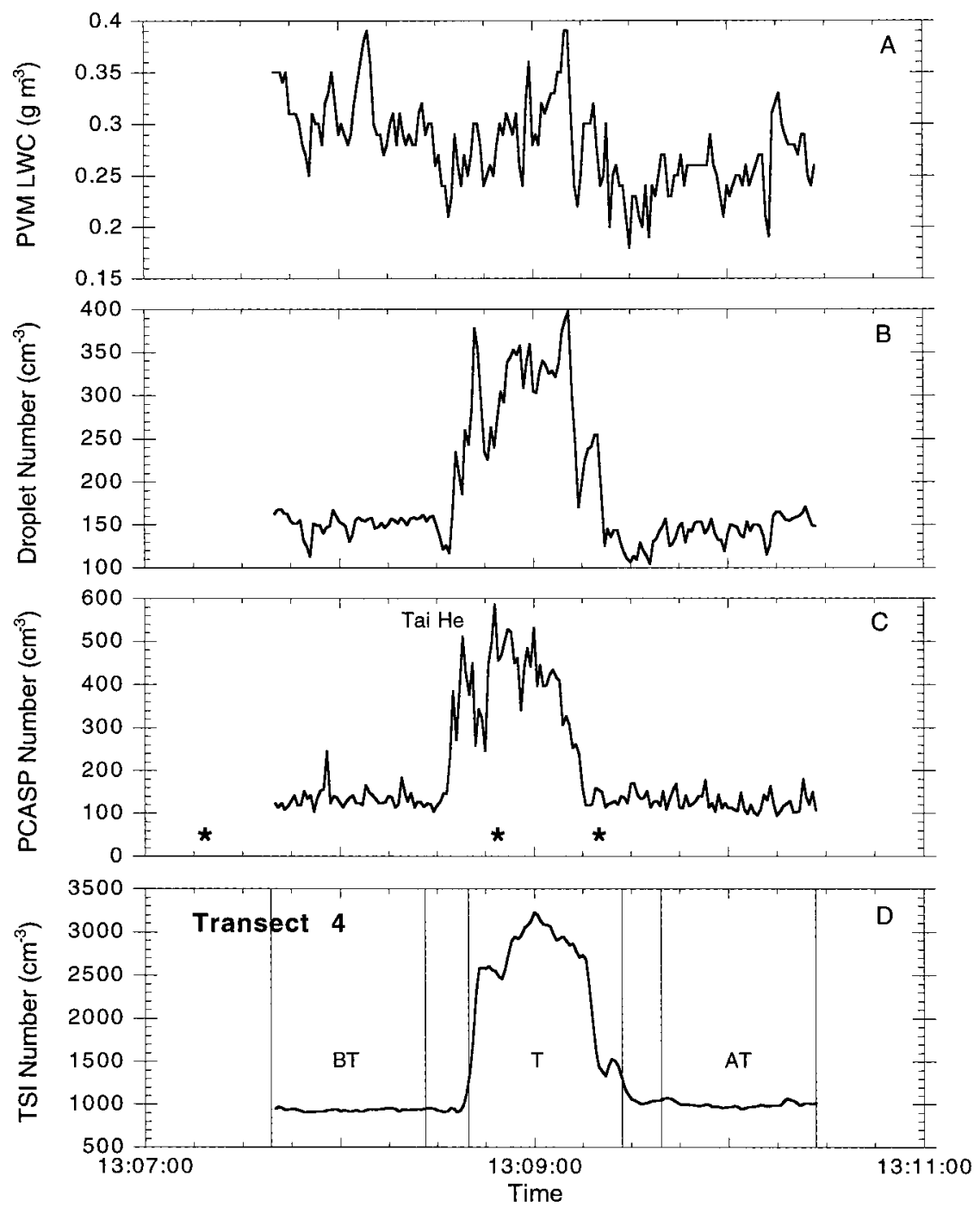

FIG. 6. Time series of measurements from the UW C-131A for transect 4 of the Tai He ship track-as in Fig. 4. No albedo measurements were available for this transect.

transects, while similar increases in accumulation-mode aerosol and droplet number were observed in four of the five transects. In the first three transects, during all of which the plume was about 50-60 min old, no substantial changes were apparent in the droplet size distributions. On the other hand, slight increases in residual particle size were observed for these cases.

For the two transects closest to the ship, clear shifts toward smaller sizes were observed in the droplet size distributions. Effective radii in track for these transects were approximately $1 \mu \mathrm{m}$ smaller than in the surrounding ambient clouds. These transects were quite similar to the ship tracks described in previous investigations (King et al. 1993; Radke et al. 1989). Interestingly, in the cases where the largest changes in droplet distributions were observed, essentially no change was seen in the residual particle distributions.

Background interstitial aerosol distributions near the
Tai He were characterized by a broad peak between about 0.01 and $0.05 \mu \mathrm{m}$, and a second smaller and more variable peak between 0.05 and $0.1 \mu \mathrm{m}$. Interstitial aerosol samples in the Tai He plumes showed large increases in particles above $0.01 \mu \mathrm{m}$, but primarily in sizes between 0.02 and $0.1 \mu \mathrm{m}$. CCN levels in the Tai He plume were on average a factor of 5 greater than background levels. Some of the track samples exhibited peaks in the range below $0.01 \mu \mathrm{m}$ as well.

\section{b. Mount Vernon}

Several transects through the Mount Vernon plume were made by the UW C-131A shortly after 1500 LT. The Mount Vernon did not produce a track on any of the satellite images. 

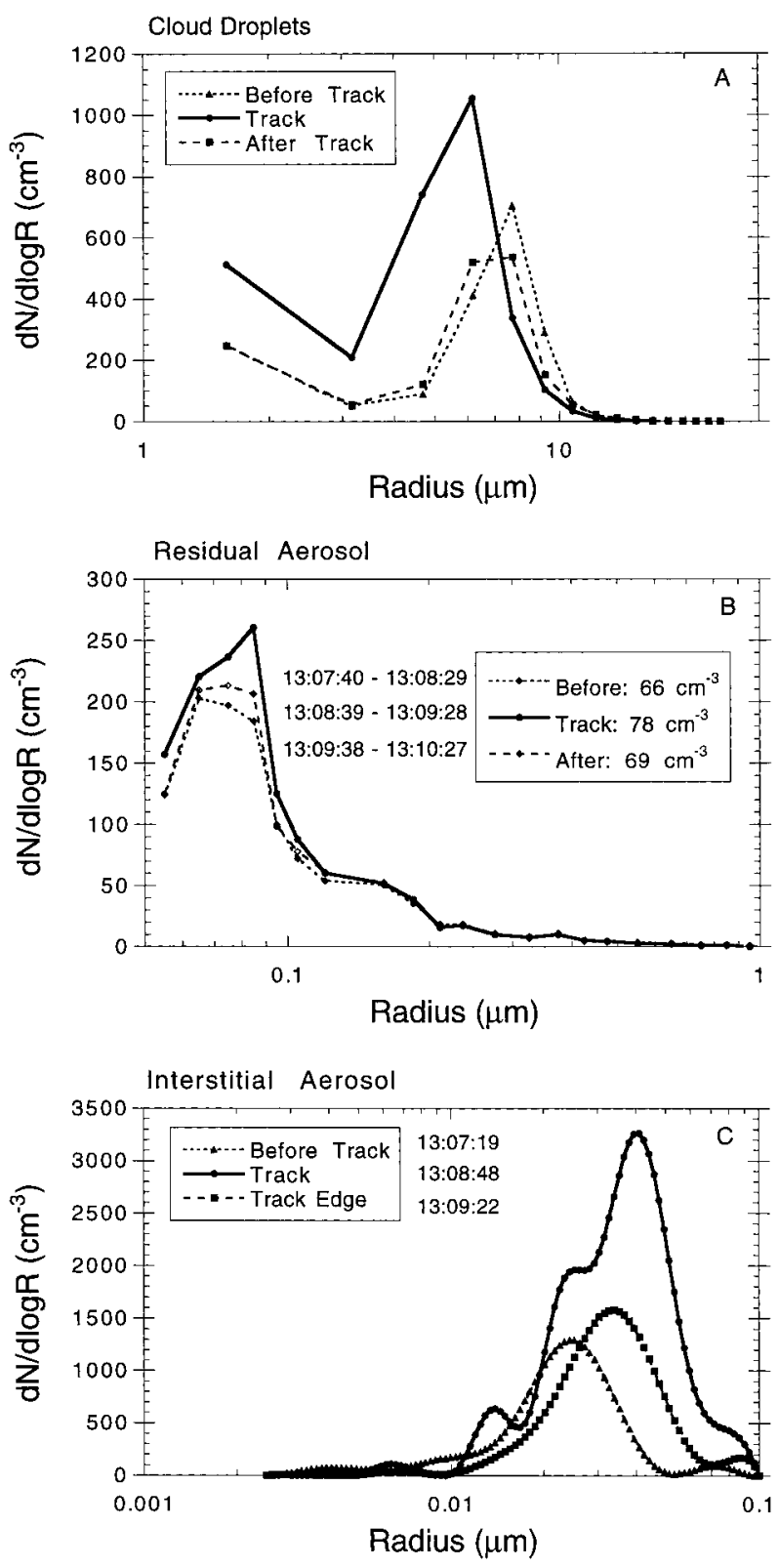

FIG. 7. Cloud and aerosol properties in transect 4 of the Tai He ship track-as in Fig. 5. Interstitial aerosol samples were taken before, in, and at the track edge in this transect.

\section{1) Transects}

Since all of the transects through the Mount Vernon effluent in cloud were quite similar, only one (transect 2) will be discussed in detail here. Since the Mount Vernon did not produce a track in the satellite imagery, the term "track" is inappropriate. We shall use the term "plume" in the following discussions when referring to the aerosol plume encountered in cloud downwind of the Mount Vernon.

\section{Transect 2}

Transect 2 of the Mount Vernon in-cloud plume was flown between about 1517 and 1520 LT for a total of $175 \mathrm{~s}$.

Time series. Figure 8 shows the time series for transect 2 of the Mount Vernon plume, approximately $2 \mathrm{~km}$ wide. Again, several peaks were seen in the total particle concentration trace shown in Fig. 8d. As in the other transects, no corresponding changes were observed in the other parameters. Accumulation-mode aerosol again showed fair variability, with an average of $70 \mathrm{~cm}^{-3}$ (std $\operatorname{dev}=32.2)$ across the transect. Droplet number was again fairly constant at $194 \mathrm{~cm}^{-3}($ std dev $=22.2)$, while LWC was more variable around a mean of $0.179 \mathrm{~g} \mathrm{~m}^{-3}$ (std dev $=0.039)$.

Cloud and aerosol properties. Figure 9 summarizes the microphysical changes through the Mount Vernon plume encountered between 1519:00 and 1519:24 LT (shaded in Fig. 8d.) Figure 9a shows drop size distributions in and outside the plume. No change in drop size distribution at all was observed in this pass. The same can be said of the residual particle size distributions, as shown in Fig. 9b. Two interstitial aerosol size distributions were taken on this pass (indicated as stars in Fig. 8d): one in the ambient cloud and one in the Mount Vernon plume. The ambient cloud distribution is similar to distributions observed neat the Tai He. There is a broad peak between 0.01 and $0.06 \mu \mathrm{m}$ and a second smaller peak between 0.06 and $0.1 \mu \mathrm{m}$. One difference between the background aerosol near the Tai $\mathrm{He}$ is the presence of a distinct third mode at $0.008 \mu \mathrm{m}$, which was not seen in the other observations. The Mount Vernon plume aerosol shows an increase in particles primarily in the range between 0.01 and $0.03 \mu \mathrm{m}$, but also in the $0.05-0.1-\mu \mathrm{m}$ range. There was an increase in cloud droplet residual particles in this size range as well in and after the plume. We have no interstitial sample after the plume, but the correspondence between the residual and interstitial particles in this case, and the fact that the residual distribution after the plume was the same as in the plume, seem to indicate that the variation in particles of this size may have been due to variation in the background aerosol and not due to plume-background differences.

\section{2) General discussion of Mount Vernon TRANSECTS}

Despite large increases in total aerosol concentration, no changes in cloud microphysics were observed in the Mount Vernon plume, and no ship track was observed in the satellite images that could be attributed to the Mount Vernon. Droplet number was relatively constant at about $200 \mathrm{~cm}^{-3}$ through all of the transects, and LWC was more variable around a mean of $0.18 \mathrm{~g} \mathrm{~m}^{-3}$. 


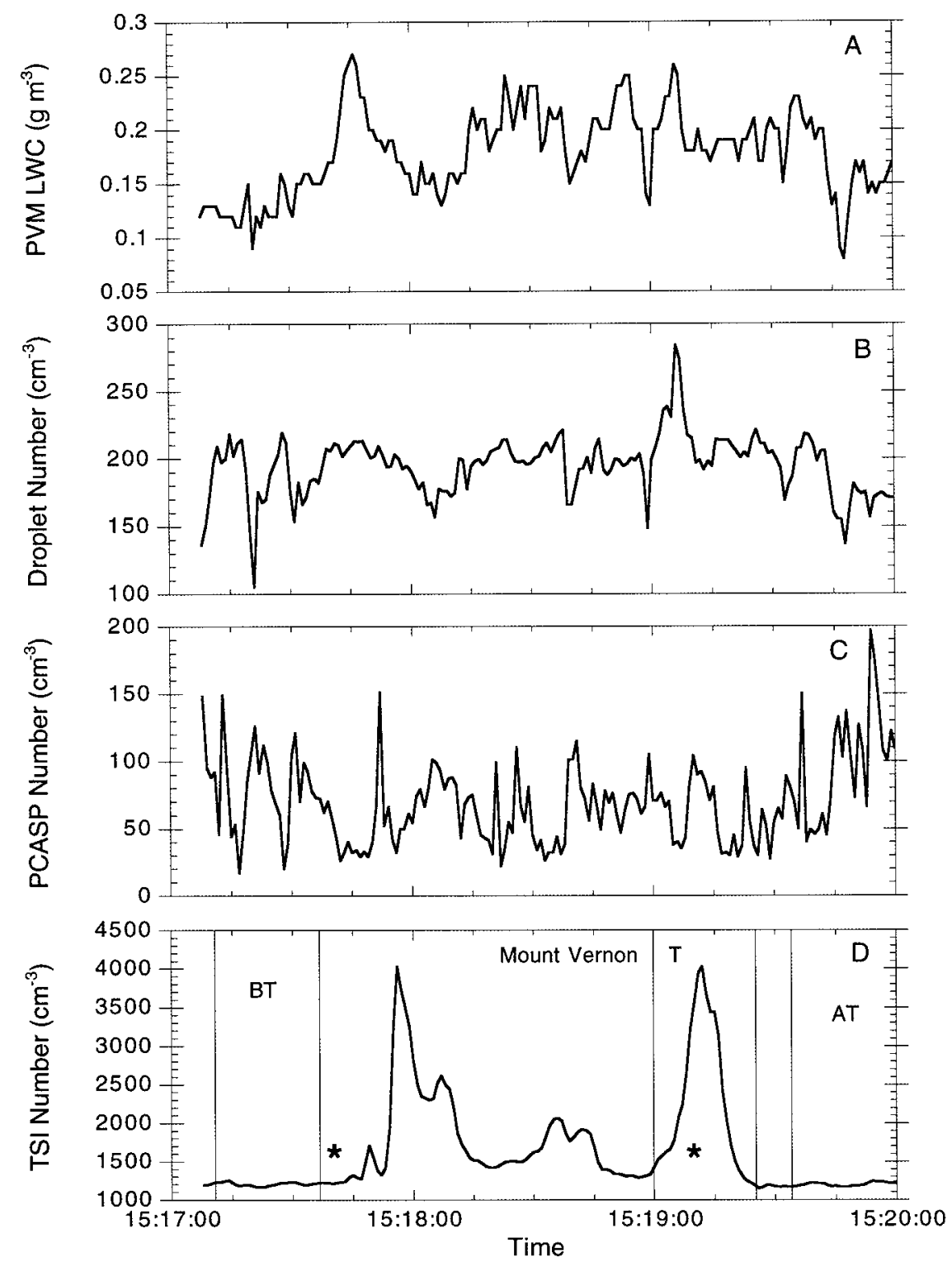

FIG. 8. Time series for transect 2 of the Mount Vernon plume. The area between the lines in (d) denotes the plume from which in-plume cloud droplet and residual particle size distributions (shown in Fig. 9) were derived.

\section{Presence/absence of a ship track: Comparisons}

Two ships close to each other in the same air mass affected the cloud deck above them in very different ways. The Tai He produced a distinct ship track in several satellite images from 27 June, while the Mount Vernon did not. In this section we contrast the two cases to see which factors exhibited the largest differences between the two cases.

\section{a. Aerosol properties}

Perhaps the largest difference in any of the aerosol properties between the Tai He and the Mount Vernon cases was in the interstitial aerosol. In the Tai He case, the ship produced an abundance of particles of all sizes above $0.01 \mu \mathrm{m}$; in particular, the concentration of particles in the $0.03-0.1-\mu \mathrm{m}$ and accumulation-mode ranges was substantially augmented in the Tai He ship tracks compared to background values. In the Mount Vernon case, similar increases in total particle concentrations were observed, but no corresponding increases in accumulation-mode particles were seen. Interstitial aerosol distributions in the Mount Vernon plume indicated that the increase in total particle number was primarily in particles smaller than circa $0.03 \mu \mathrm{m}$. Apparently these particles were too small to have activated under the 

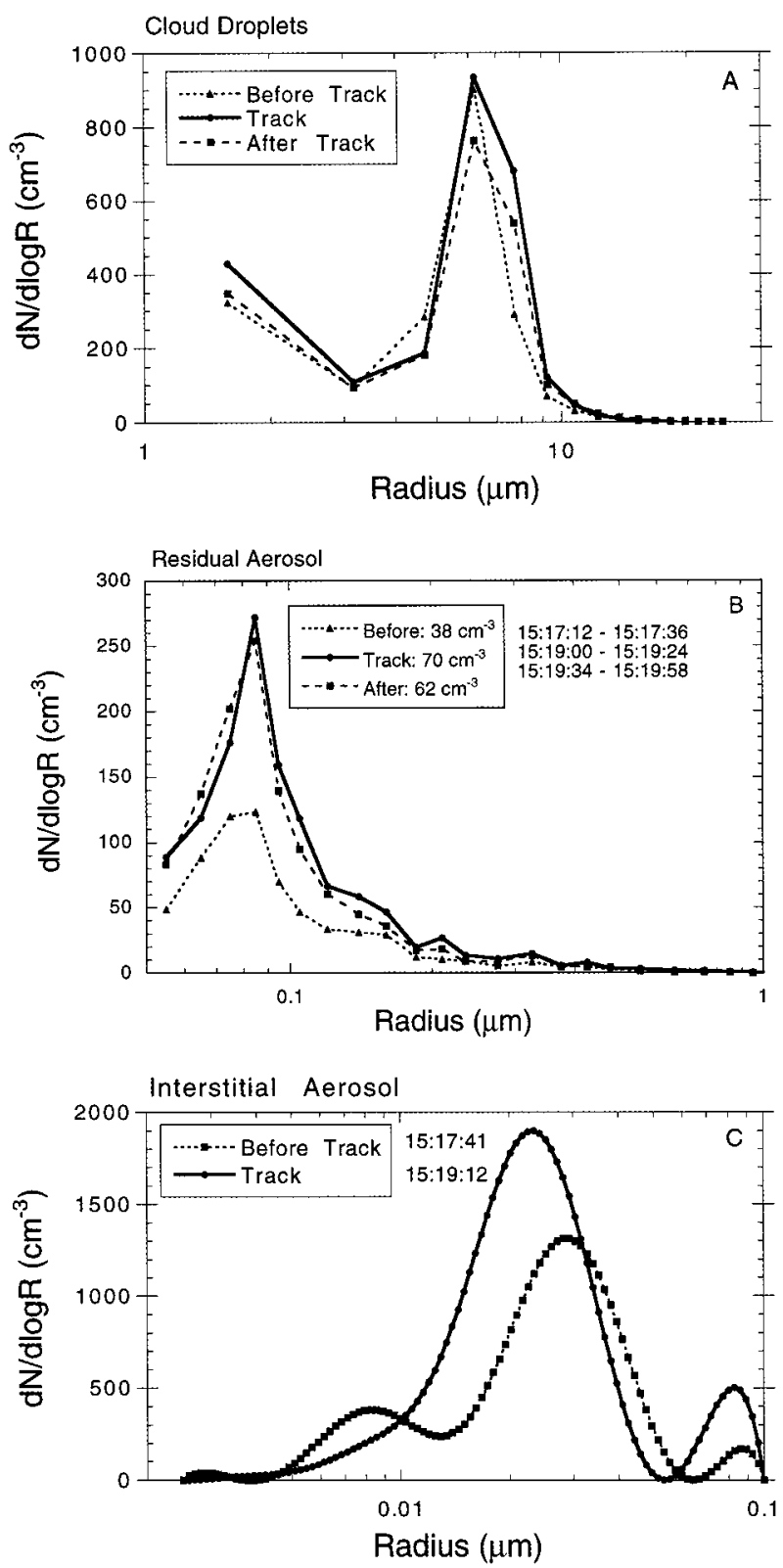

FIG. 9. Cloud droplet (a), droplet residual aerosol (b), and interstitial aerosol size distributions (c) for transect 2 of the Mount Vernon plume.

prevailing supersaturations in the clouds near the Mount Vernon, while the larger particles from the Tai He were able to grow to form cloud droplets. This conjecture is supported by an analysis of emissions from a large number of ships encountered during the MAST experiment (Hobbs et al. 2000) and by the observation that the Tai $H e$ produced more than double the number of $\mathrm{CCN}$ active at $1 \%$ supersaturation than did the Mount Vernon.

While it is not surprising that smaller particles are less active in cloud drop formation, the observed differences in particle characteristics can provide information relevant to the broader issue of indirect radiative forcing of aerosols. The differences in aerosol characteristics for the two ships allows us to estimate the smallest size of particle able to influence the microphysics and radiative properties of the clouds we encountered on this particular day. Öström et al. (2000) concluded that the number population of cloud droplets for the entire MAST experiment was controlled by particles smaller than $0.1-\mu \mathrm{m}$ radius and that this upper limit of particle size controlling droplet number did not vary significantly with boundary layer pollution level. On this particular day, we can estimate that the lower size limit for particles controlling droplet number was about $0.02-0.04-\mu \mathrm{m}$ radius.

Present attempts to model indirect forcing on a global scale use various empirical relationships between aerosol sulfate mass and cloud albedo, even though the physics behind albedo change in clouds is a number-based rather than a mass-based phenomenon. If we can determine a size range of aerosol particles that dominates cloud droplet number for low-level marine clouds, it may be able to improve the parameterizations used in global models by providing a more logical link between aerosol mass and particle number.

An interesting difference in particle chemistry from single particle analysis between the Tai He and Mount Vernon was the presence of particles containing silicon and organic material in the Tai He plume but not in the Mount Vernon plume. The Tai He burned diesel fuel, and silicon is used in the distillation cracking process, so traces of silicon are present in diesel fuel. The Mount Vernon was driven by a steam turbine, which burns navy distillate fuel. No substantial differences in bulk analysis of the major ionic species were observed in the tracks or plumes of the ships, indicating that the particles produced by the ships (and in the Tai He case responsible for the ship track effect) were small and did not contribute in any tangible way to the particle mass in the boundary layer.

\section{b. Cloud properties}

Clear decreases in droplet size were observed in two of the Tai He transects, and in none of the Mount Vernon passes. Droplet concentrations in the background clouds near the Tai He were slightly lower than near the Mount Vernon: 150 versus $200 \mathrm{~cm}^{-3}$, respectively. It is not likely that this difference alone could account for the fact that the Mount Vernon did not produce a track while the Tai He did. Ship tracks were observed in even more polluted clouds during the experiment (Noone et al. 2000). Cloud droplet number was not any more variable in either location. The relative standard deviation of droplet number was $8 \%$ near the Tai $\mathrm{He}$ and $11 \%$ near the Mount Vernon.

\section{Summary and conclusions}

We have presented a case study of ship track formation in semipolluted clouds off the coast of central 
California. We have compared and contrasted the effects that two different ships in the same air mass had on clouds in the marine boundary layer. One of the ships (the Tai $\mathrm{He}$ ) produced a distinct ship track in satellite imagery, while the other ship (the USS Mount Vernon) did not. We wished to answer six questions regarding the nature of the backgound clouds in which ship tracks were forming, the differences in cloud and aerosol properties between the background clouds and a specific ship track, and the reasons why the Tai He caused a ship track and the Mount Vernon did not when both ships were in the same air mass.

Concerning the properties of the background clouds, we estimate that sea salt particles accounted for approximately $15 \%$ of the cloud droplet nuclei in the ambient clouds. Organic particles could account for approximately $6 \%-9 \%$ of the cloud droplet nuclei. The rest of the cloud droplet nuclei (about 76\%) were estimated to be partially neutralized sulfate particles. Aerosol mass scavenging efficiencies in the background clouds were typically between $80 \%$ and $95 \%$, while the number scavenging efficiency for accumulation-mode particles was approximately $80 \%$.

From the point of view of ship track formation, no differences in sea salt concentrations that we could link to ship track formation were seen between the ambient clouds and ship tracks. The high values of the accumulation-mode number and mass scavenging efficiencies (about 85\%-95\% and 77\%, respectively) in the background clouds indicate that the microphysical properties of the clouds could be susceptible to an additional source of particles in this size range.

Perhaps the most important difference between the two ships in terms of track formation was in the size of the submicrometer aerosol produced by the ships. The Tai He, burning diesel fuel, produced substantial numbers of particles in the size range between 0.01 and $0.1 \mu \mathrm{m}$, while the Mount Vernon, driven by a turbine engine, produced particles generally smaller than 0.03 $\mu \mathrm{m}$. The fact that the larger particles (accumulationmode particles and particles down to circa 0.03-0.04 $\mu \mathrm{m})$ produced by the Tai He were able to form additional cloud droplets in the tracks was supported by the significantly higher CCN flux in the Tai He plume compared with the Mount Vernon plume. The observed differences allow us to estimate that the lower limit of particle size that could affect cloud properties on this day was between $0.02-$ and $0.04-\mu \mathrm{m}$ radius.

Acknowledgments. We are indebted to the pilots, captain and crews of the UW C-131A, the MRF C-130, the NRL airship, and the R/V Glorita for their excellent work during the field campaign. Drs. Wendell Nuss and Chuck Wash at NPS provided valuable forecasting and meteorological analysis during the campaign. This project was funded by the Office of Naval Research. The support provided by Bob Bluth from ONR was indis- pensable, and the project would not have been a success without his efforts.

\section{REFERENCES}

Bernard, P., R. Van Grieken, and D. Eisma, 1986: Classification of estuarine particles using electron microprobe analysis and multivariate techniques. Environ. Sci. Technol., 20, 467-473.

Brown, P. R. A., 1993: Measurements of the ice water content in cirrus using an evaporative technique. J. Atmos. Oceanic Technol., 10, 579-590.

Clarke, A. D., N. C. Ahlquist, and D. S. Covert, 1987: The Pacific marine aerosol: Evidence for natural acid sulfates. J. Geophys. Res., 92D, 4179-4190.

Coakley, J. A., Jr., R. L. Bernstein, and P. A. Durkee, 1987: Effect of ship-stack effluents on cloud reflectivity. Science, 237, 10201022.

Conover, J. H., 1966: Anomalous cloud lines. J. Atmos. Sci., 23, 778785.

Durkee, P. A., and Coauthors, 2000a: Composite ship track characteristics. J. Atmos. Sci., 57, 2542-2553.

- K. J. Noone, and R. T. Bluth, 2000b: The Monterey Area Ship Track experiment. J. Atmos. Sci., 57, 2523-2541.

- , and Coauthors, 2000c: The impact of ship-produced aerosols on the microstructure and albedo of warm marine stratocumulus clouds: A test of MAST hypotheses $1 \mathrm{i}$ and 1ii. J. Atmos. Sci., 57, 2554-2569.

Ferek, R. J., D. A. Hegg, and P. V. Hobbs, P. A. Durkee, and K. Nielsen, 1998: Measurements of ship-induced tracks in clouds off the Washington coast. J. Geophys. Res., 103, 23 199-23 206.

- and Coauthors, 2000: Drizzle suppression in ship tracks. $J$. Atmos. Sci., 57, 2707-2728.

Flossmann, A. I., W. D. Hall, and H. R. Pruppacher, 1985: A theoretical study of the wet removal of atmospheric pollutants. Part I: The redistribution of aerosol particles captured through nucleation and impaction scavenging by growing cloud drops. $J$. Atmos. Sci., 42, 583-606.

Hindman, E. E., W. M. Porch, J. G. Hudson, and P. A. Durkee, 1994: Ship-produced cloud lines of 13 July 1991. Atmos. Environ., 28, 3393-3403.

Hobbs, P. V., L. F. Radke, J. H. Lyons, R. J. Ferek, D. J. Coffman, and T. J. Casadevall, 1991: Airborne measurements of particle and gas emissions from the 1990 volcanic eruptions of Mount Redoubt. J. Geophys. Res., 96, $18735-18752$.

— , and Coauthors, 2000: Emissions from ships with respect to their effects on clouds. J. Atmos. Sci., 57, 2570-2590.

Hoppel, W. A., G. M. Frick, and R. E. Larson, 1986: Effect of nonprecipitating clouds on the aerosol size distribution in the marine boundary layer. Geophys. Res. Lett., 13, 125-128.

,-- J. W. Fitzgerald, and B. J. Wattle, 1994: A cloud chamber study of the effect that nonprecipitating water clouds have on the aerosol size distribution. Aerosol Sci. Technol., 20, 1-30.

Hudson, J. G., 1989: An instantaneous CCN spectrometer. J. Atmos. Oceanic Technol., 6, 1055-1065.

_ , and P. R. Frisbie, 1991: Cloud condensation nuclei near marine stratus. J. Geophys. Res., 96, 20 795-20 808.

Jambers, W., L. De Bock, and R. Van Grieken, 1995: Recent advances in the analysis of individual environmental particles. Analyst, 120, 681-692.

Kilsby, C. G., D. P. Edwards, R. W. Saunders, and J. S. Foot, 1992: Water vapour continuum absorption in the tropics: Aircraft measurements and model comparisons. Quart. J. Roy. Meteor. Soc., 118, 715-748.

Kim, Y., and R. D. Cess, 1993: Effect of anthropogenic sulfate aerosols on low-level cloud albedo over oceans. J. Geophys. Res., 98, $14883-14885$.

King, M. D., L. F. Radke, and P. V. Hobbs, 1993: Optical properties of marine stratocumulus clouds modified by ships. J. Geophys. Res., 98, 2729-2739. 
Martin, G. M., D. W. Johnson, and A. Spice, 1994: The measurement and parameterization of effective radius of droplets in warm stratocumulus clouds. J. Atmos. Sci., 51, 1823-1842.

Noone, K. J., J. A. Ogren, J. Heintzenberg, R. J. Charlson, and D. S. Covert, 1988: Design and calibration of a counterflow virtual impactor for sampling of atmospheric fog and cloud droplets. Aerosol Sci. Technol., 8, 235-244.

- , and Coauthors, 1992: Changes in aerosol size and phase distributions due to physical and chemical processes in fog. Tellus, 44B, 489-504.

— , and Coauthors, 2000: A case study of ship track formation in a polluted marine boundary layer. J. Atmos. Sci., 57, 2748-2764.

O’Dowd, C. D., and M. H. Smith, 1993: Physicochemical properties of aerosols over the northeast Atlantic: Evidence for wind speedrelated submicron sea-salt aerosol production. J. Geophys. Res. 98, 1137-1149.

Ogren, J. A., J. Heintzenberg, and R. J. Charlson, 1985: In-situ sampling of clouds with a droplet to aerosol converter. Geophys. Res. Lett., 12, 121-124.

Öström, E., K. J. Noone, and R. A. Pockalny, 2000: Cloud droplet residual particle microphysics in marine stratocumulus clouds observed during the Monterey Area Ship Track experiment. J. Atmos. Sci., 57, 2671-2683.

Petersen, W. B., and L. G. Lavdas, 1986: Inpuff 2.0-A multiple source Gaussian puff dispersion algorithm. EPA/600/8-86/024, U.S. Environmental Protection Agency, Research Triangle Park, $\mathrm{NC}, 110 \mathrm{pp}$.

Platnick, S., and S. Twomey, 1994: Determining the susceptibility of cloud albedo to changes in droplet concentration with the Advanced Very High Resolution Radiometer. J. Appl. Meteor., 33, 334-347.
Radke, L. F., J. A. Coakley Jr., and M. D. King, 1989: Direct and remote sensing observations of the effects of ships on clouds. Science, 246, 1146-1149.

Rogers, D. P., D. W. Johnson, and C. A. Friehe, 1995: The stable internal boundary layer over a coastal sea. Part I: Airborne measurements of the mean and turbulence structure. J. Atmos. Sci., 52, 667-683.

Russell, L. M., R. C. Flagan, and J. H. Seinfeld, 1995: Asymmetric instrument response resulting from mixing effects in accelerated DMA-CPC measurements. Aerosol Sci. Technol., 23, 491-509. , K. J. Noone, R. J. Ferek, R. A. Pockalny, R. C. Flagan, and J. H. Seinfeld, 2000: Combustion organic aerosol as cloud condensation nuclei in ship tracks. J. Atmos. Sci., 57, 2591-2606.

Saunders, R. W., G. Brogniez, J. C. Buriez, R. Meerkötter, and P. Wendling, 1992: A comparison of measured and modeled broadband fluxes from aircraft data during the ICE' 89 field experiment. J. Atmos. Oceanic Technol., 9, 391-406.

Schwartz, S. E., 1988: Are global cloud albedo and climate controlled by marine phytoplankton? Nature, 336, 441-445.

Twomey, S., 1974: Pollution and the planetary albedo. Atmos. Environ., 8, 1251-1256.

_ 1977: Atmospheric Aerosols. Elsevier Scientific, 302 pp.

- 1991: Aerosols, clouds and radiation. Atmos. Environ., 25A, 2435-2442.

— "Anomalous cloud lines." J. Atmos. Sci., 25, 333-334.

Wolfenbarger, J. K., and J. H. Seinfeld, 1990: Inversion of aerosol size distribution data. J. Aerosol Sci., 21, 227-247.

Zhang, S.-H., Y. Akutsu, L. M. Russell, R. C. Flagan, and J. H. Seinfeld, 1995: Radial differential mobility analyzer. Aerosol Sci. Technol., 23, 357-372. 